\title{
Stratospheric warming influence on the mesosphere/lower thermosphere as seen by the extended CMAM
}

\author{
M. G. Shepherd, S. R. Beagley, and V. I. Fomichev \\ Centre for Research in Earth and Space Science, York University, Toronto, Canada \\ Correspondence to: M. G. Shepherd (mshepher@yorku.ca)
}

Received: 26 December 2013 - Revised: 16 March 2014 - Accepted: 22 April 2014 - Published: 3 June 2014

\begin{abstract}
The response of the upper mesosphere/lower thermosphere region to major sudden stratospheric warming (SSW) is examined employing temperature, winds, $\mathrm{NO}_{\mathrm{X}}$ and $\mathrm{CO}$ constituents from the extended Canadian Middle Atmosphere Model (CMAM) with continuous incremental nudging below $10 \mathrm{hPa}(\sim 30 \mathrm{~km})$. The model results considered cover high latitudes $\left(60-85^{\circ} \mathrm{N}\right)$ from 10 to $150 \mathrm{~km}$ height for the December-March period of 2003/2004, 2005/2006 and 2008/2009, when some of the strongest SSWs in recent years were observed. $\mathrm{NO}_{\mathrm{X}}$ and $\mathrm{CO}$ are used as proxies for examining transport. Comparisons with ACE-FTS (Atmospheric Chemistry Experiment-Fourier Transform Spectrometer) satellite observations show that the model represents well the dynamics of the upper mesosphere/lower thermosphere region, the coupling of the stratospheremesosphere, and the $\mathrm{NO}_{\mathrm{X}}$ and $\mathrm{CO}$ transport. New information is obtained on the upper mesosphere/lower thermosphere up to $150 \mathrm{~km}$ showing that the $\mathrm{NO}_{\mathrm{X}}$ volume mixing ratio in the 2003/2004 winter was very perturbed indicating transport from the lower atmosphere and intense mixing with large $\mathrm{NO}_{\mathrm{X}}$ influx from the thermosphere compared to 2006 and 2009. These results, together with those from other models and observations, clearly show the impact of stratospheric warmings on the thermosphere.
\end{abstract}

Keywords. Atmospheric composition and structure (middle atmosphere - composition and chemistry)

\section{Introduction}

The last decade has been marked by a number of very intense major sudden stratospheric warmings (SSW) in the winter Northern Hemisphere, leading to a very perturbed and dynamically active middle atmosphere. A lot of attention has been given to the stratospheric warmings which occurred in 2004, 2006 and 2009 (e.g. Manney et al., 2005, 2008a, b, 2009; Funke et al., 2005; Randall et al., 2006, 2009; Hauchecorne et al., 2007; Orsolini et al., 2010; Kvissel et al., 2012) and their effect on the middle atmosphere coupling not only because these SSW events were massive and their effects were felt throughout the middle atmosphere, but also because a number of satellite experiments operating at that time (SABER/TIMED (the Sounding of the Atmosphere using Broadband Emission Radiometry/the Thermosphere Ionosphere Mesosphere Energetics Dynamics satellite), ACEFTS (Atmospheric Chemistry Experiment-Fourier Transform Spectrometer), Odin/SMR (Sub-Millimeter Radiometer), MIPAS (Michelson Interferometer for Passive Atmospheric Sounding)/Envisat, GOMOS (Global Ozone Monitoring by Occultation of Stars)/Envisat, MLS (Microwave Limb Sounder-Aura)) were able to provide global coverage of the dynamic response of atmospheric temperature and wind fields as well as various trace gases, to this phenomenon.

The SSW is caused by the interaction of planetary waves with the mean flow in the upper stratopause leading to an upward- and poleward-directed heat flux (Matsuno, 1971). According to the World Meteorological Organization (WMO) definition a major stratospheric sudden warming requires that at the $10 \mathrm{hPa}$ pressure level $(\sim 30 \mathrm{~km}$ height $)$ or below there are (1) a latitudinal mean temperature increase poleward of $60^{\circ}$ latitude, and (2) an associated circulation reversal. The SSW onset is marked by dramatic rise of temperature over the winter pole by as much as $60 \mathrm{~K}$ and a reversal of the zonal wind direction from eastward to westward. The warming appears at high levels first and descends into the lower stratosphere. The recovery of the 
polar atmosphere from the major SSW is marked by the reappearance of the warm stratopause layer around its climatological position and the slow return of the zonal wind from westward (negative) back to the pre-warming eastward (positive). It takes usually 4-6 weeks for the zonal mean circulation to be restored to its pre-warming state. A detailed description of the SSW morphology can be found for example in Schoeberl (1978), Andrews et al. (1987), and Limpasuvan et al. (2004) and the references therein.

Ground-based optical observations of hydroxyl and oxygen airglow emission rates and rotational temperatures at high Arctic latitudes $\left(80^{\circ} \mathrm{N}\right)$ in the winter of $2008 / 2009$ allowed the examination of the effect of the SSW on these emissions nominally assigned to peak altitudes of $\sim 87$ and $94 \mathrm{~km}$, respectively. Shepherd et al. (2010) reported depleted airglow emission rates (by a factor of 7) and a 50-60 K decrease in the rotational temperatures at the time of the SSW. During the recovery phase the temperatures returned to their pre-event values, while there was an enhancement in the observed emission rates. After calibrating the ground-based $\mathrm{OH}$ emission rate observations to those observed by SABER it was found that the height of the $\mathrm{OH}$ emission rate peak varied from 86 to $91 \mathrm{~km}$ at the time of the SSW onset and descended to $78-79 \mathrm{~km}$ during the SSW recovery phase.

Modelling of the $\mathrm{O}$ volume mixing ratio (VMR), corresponding to the observed $\mathrm{OH}$ and $\mathrm{O}_{2}(0,1)$ airglow integral emission rates, following the work by Ward (1999) showed atomic oxygen depletion by a factor of $\sim 5$ during the SSW that lasted over a number of days. During the SSW recovery phase the $\mathrm{O}$ VMR giving rise to the observed $\mathrm{O}_{2}(0,1)$ airglow emission rates increased by a factor of 3.5 from its preSSW level and 17 times from the peak of the SSW, while that of the $\mathrm{OH}$ returned to its pre-SSW level. These results suggested that at altitudes below $\sim 90 \mathrm{~km}$ the effect of the SSW on the mesosphere as seen in the perturbations of the $\mathrm{OH}$ peak altitude, airglow emission rates and temperatures was expressed as an upwelling with the airglow layers reaching unusually high altitudes of $91 \mathrm{~km}$ for the $\mathrm{OH}$ airglow. Preceding the split of the polar vortex, a decrease of the $\mathrm{O}$ volume mixing ratio and adiabatic cooling were also observed. A weak downwelling followed, coupled with horizontal motions in the form of 12 and $8 \mathrm{~h}$ waves, which restored the $\mathrm{O}$ volume mixing ratio to levels comparable to those prior to the SSW event (Shepherd et al., 2010).

The variability seen in the $\mathrm{O}_{2}$ atm. emission led Shepherd et al. (2010) to suggest that in the upper mesosphere and lower thermosphere (UMLT) region above $90 \mathrm{~km}$ the SSW recovery phase was marked by downwelling and dramatic influx of atomic oxygen from the thermospheric reservoir, significantly increasing the $\mathrm{O}$ volume mixing ratio with respect to its pre-SSW state. This infilling overshot the normal levels, increasing the $\mathrm{O}$ volume mixing ratio to values $\sim 4$ times the normal ones and clearly indicated that the thermosphere was significantly perturbed by the major SSW in January 2009.
The effect of SSW on the upper mesosphere and thermosphere was further examined by Shepherd and Shepherd (2011) employing WINDII (Wind Imaging Interferometer) (Shepherd et al., 1993) satellite observations of $\mathrm{O}\left({ }^{1} \mathrm{~S}\right)$ dayglow volume emission rate (VER) in the altitude range from 80 to $300 \mathrm{~km}$ and from 50 to $70^{\circ} \mathrm{N}$, observed during the stratospheric warming event in February 1993 (Whiteway and Carswell, 1994; Shepherd et al., 1999; Walterscheid et al., 2000). Of particular interest was the response of thermospheric $\mathrm{O}\left({ }^{1} \mathrm{~S}\right)$ dayglow as a proxy for SSW-induced variations in the $\mathrm{O}$ volume mixing ratio. The WINDII thermospheric $\mathrm{O}\left({ }^{1} \mathrm{~S}\right)$ VER showed a depletion above $140 \mathrm{~km}$ in the daytime $\mathrm{O}\left({ }^{1} \mathrm{~S}\right)$ VER, which commenced around the onset of the SSW and lasted over a period of 3-4 days before returning to and exceeding the pre-SSW values during the SSW recovery phase, an effect similar to that reported by Shepherd et al. (2010) for the mesosphere and lower thermosphere region at $80^{\circ} \mathrm{N}$ and consistent with a transport-induced depletion of $\mathrm{O}\left({ }^{1} \mathrm{~S}\right)$ VER above $140 \mathrm{~km}$, which commenced a little before or around the beginning of the SSW and lasted throughout the SSW event.

Below $\sim 140 \mathrm{~km}$ height the fourfold enhancement in the $\mathrm{O}\left({ }^{1} \mathrm{~S}\right)$ VER at $\sim 100 \mathrm{~km}$ was correlated with the temperature anomalies of the SSW at the stratopause and in the upper mesosphere as observed by WINDII and reported by Shepherd and Shepherd (2011). Although the SSW in February 1993 was far weaker than the recent SSW events from 2004, 2006 and 2009, the direct observations made possible by WINDII for the earlier dates clearly showed the influence of the SSW on the thermosphere, at least up to $200 \mathrm{~km}$. The effect on the thermospheric O VMR for the recent SSW dates would have been much greater as was alluded to by results reported by Shepherd et al. (2010), which is part the motivation behind the current study.

It is well accepted now that in the upper stratosphere and the mesosphere-thermosphere the $\mathrm{NO}_{\mathrm{X}}$ is predominantly $\mathrm{NO}+\mathrm{NO}_{2}$ and its distribution is influenced by the mean meridional circulation (Solomon et al., 1982; Salmi et al., 2011, and references therein) or more likely horizontal mixing of tropical air with low $\mathrm{NO}_{\mathrm{X}}$ into the polar region. In the upper mesosphere $\mathrm{NO}_{\mathrm{X}}$ is mostly $\mathrm{NO}$, but as it descends below $70 \mathrm{~km}$ it is converted to $\mathrm{NO}_{2}$ (Solomon et al., 1982; Brasseur and Solomon, 2005). Recent observations have shown that in wintertime $\mathrm{NO}_{\mathrm{X}}$ can effectively be transported downwards inside the polar vortex through vertical and horizontal mixing after it has been produced in the UMLT region (Solomon et al., 1982; Siskind et al., 2000; Funke et al., 2005, 2007; Hauchecorne et al., 2007; Seppälä et al., 2007; Randall et al., 2007). Russell et al. (1993) showed that the stratospheric vortex allows mesospheric air to descend deep into the stratosphere during the polar night and was linked to the catalytic destruction of $\mathrm{O}_{3}$ (Randall et al., 1998, 2001, 2005; Siskind et al., 2000; Semeniuk et al., 2011). Clilverd et al. (2007) were the first to use low-frequency radio wave remote sensing to show the connection of observed 
enhanced mesospheric ionization with the enhanced $\mathrm{NO}_{\mathrm{X}}$ influx from the thermosphere into the mesosphere and upper stratosphere resulting from energetic particle precipitation (EPP) and a strong polar vortex. Energetic $(>10 \mathrm{MeV})$ solar protons from coronal mass ejections, low-energy electrons $(1-10 \mathrm{keV})$ from the magnetosphere during geomagnetically disturbed periods, and high-energy electrons ( $10 \mathrm{keV}-\mathrm{a}$ few $\mathrm{MeV}$ ) from the inner magnetosphere and/or plasma sheet precipitate at polar latitudes and at heights depending on their energy (Turunen et al., 2009). These energetic particles interact with the neutral atmospheric gases and change the concentration of minor tracers like the $\mathrm{NO}_{\mathrm{X}}$. During aurora the concentration of $\mathrm{NO}$ is directly enhanced by the precipitation of low-energy electrons into the lower thermosphere. At high latitudes such enhanced $\mathrm{NO}_{\mathrm{X}}$ has been observed to descend into the mesosphere and upper stratosphere (e.g. Siskind and Russell III, 1996). Various studies have shown that $\mathrm{NO}_{\mathrm{X}}$ transport can provide a connection between the ozone observed in the stratosphere and the energetic particle precipitation in the UMLT region (e.g. Solomon et al., 1982; Siskind et al., 1997, 1998). The large $\mathrm{NO}_{\mathrm{X}}$ in the winter polar region results from the strong downward motion, which advects $\mathrm{NO}_{\mathrm{X}}$-rich parcels of air from the winter MLT downward. In the lower thermosphere $\mathrm{NO}_{\mathrm{X}}$ is produced by photoionization of $\mathrm{N}_{2}$ by extreme ultraviolet (EUV) and soft X-rays, while at high latitudes the primary source of $\mathrm{NO}_{X}$ is ionizing energetic particle precipitation, from thermosphere to stratosphere (Barth, 1992; Barth et al., 1999, 2003; Vitt et al., 2000), while the $\mathrm{NO}_{\mathrm{X}}$ loss is driven by photodissociation. Most of the recent and current satellite experiments provide observations below $100 \mathrm{~km}$ (MIPAS being an exception with a few selected cases; Funke et al., 2005,2010 ), and thus the dynamic response of the thermosphere to the recent SSW still remains pretty much unknown. Model simulations of the state of the middle atmosphere during these SSWs have been predominantly for altitudes below $100 \mathrm{~km}$. WINDII still remains the only satellite experiment which provided observations of thermospheric oxygen airglow emissions, temperature and winds, but it operated during a period (1991-2003) when no major stratospheric warmings were observed (Manney et al., 2005; Kvissel et al., 2012). The ground-based airglow and temperature observations (Shepherd et al., 2010) showed a SSW effect extending into the UMLT region, but could not provide a comprehensive picture of the vertical and global extent of the SSW into the thermosphere. To bridge all these observations and examine the stratosphere-thermosphere coupling during the SSWs in 2004, 2006 and 2009 the extended Canadian Middle Atmosphere Model (CMAM) with continuous incremental nudging (CIN) has been employed over the altitude range from 10 to $200 \mathrm{~km}$ and the results obtained are presented and discussed in this paper. The paper is organized as follows: Sect. 2 describes the extended CMAM-CIN, Sect. 3 examines the variability of the modelled temperature and wind fields during the three winter seasons of 2003/2004,
$2005 / 2006$ and 2008/2009 as well as the $\mathrm{CO}$ and $\mathrm{NO}_{\mathrm{X}}$ as proxies for transport. The results obtained are discussed in Sect. 4 in the context of available experimental data, and the conclusions are summarized in Sect. 5.

\section{The extended CMAM-CIN}

The extended CMAM (Beagley et al., 2000; Fomichev et al., 2002; McLandress et al., 2006; Beagley et al., 2010) is one of the first ground-to-thermosphere general circulation models in the world and is based on the regular version of the CMAM described by Beagley et al. (1997). The primary rationale for the extended CMAM is to examine the nature of the physical and dynamical processes in the mesosphere/lower thermosphere region without the artificial effects of an imposed sponge layer which can modify the circulation in an unrealistic manner. It gave the capability of modelling the physics and dynamics of the atmosphere from the ground to approximately $250 \mathrm{~km}$, thus providing a powerful tool for comparisons with satellite observational data like those from the Upper Atmosphere Research Satellite (UARS) and the Thermosphere Ionosphere Mesosphere Energetics and Dynamics (TIMED). The most recent version of the extended CMAM (Beagley et al., 2010) has incorporated neutral and simplified ion chemistry, actively simulating $99 \%$ of the atmosphere's constituents except for noble gases which are specified.

The model version used in the current study employs a T47 spectral truncation, with a Gaussian collocation grid of $96 \times 48$ points and with 95 levels in the vertical that extend from the ground to $2 \times 10^{-7} \mathrm{hPa}(200-300 \mathrm{~km}$ depending on the phase of the solar cycle). This corresponds to a horizontal resolution of about $4^{\circ}\left(3.75^{\circ}\right)$ and a vertical resolution of $0.35 \mathrm{log}$-pressure scale height in the middle and upper atmosphere (approximately $2.5 \mathrm{~km}$ between 30 and $100 \mathrm{~km}$ and grows in the thermosphere, reaching about $10 \mathrm{~km}$ and $15 \mathrm{~km}$ near 150 and $200 \mathrm{~km}$, respectively). For the periods considered in this study characterized by low solar activity (minimum of the 11-year solar cycle) the altitude range extends to a height of about $200 \mathrm{~km}$. Parameterizations of the most important physical processes from the surface to the lower thermosphere are included. Those pertaining to the upper atmosphere are described in Fomichev et al. (2002); they include breakdown of local thermodynamical equilibrium treatment of both solar heating and infrared cooling, EUV solar heating, molecular diffusion and viscosity, simplified ion drag, and the effects of momentum and energy deposition by unresolved non-orographic gravity waves (GWs) together with the inclusion of eddy diffusion generated by gravity wave breaking. The parameterized gravity wave drag scheme for non-orographic waves is according to that described by Hines (1997). Molecular diffusion and gas separation occur with the increase of height in the atmosphere. The model also has comprehensive stratospheric chemistry and a simplified ion chemistry scheme (Beagley et al., 2010) 
Table 1a. Photoionozation processes in the extended CMAM.

\begin{tabular}{llll}
\hline & Reaction & $J_{\infty}$ & References \\
\hline $\mathrm{O}_{2}+h v$ & $\rightarrow \mathrm{O}_{2}^{+}+e$ & $4.94 \times 10^{-7}$ & Solomon and Qian (2005) \\
$\mathrm{O}_{2}+h v$ & $\rightarrow \mathrm{O}^{+}+\mathrm{O}+e$ & $1.21 \times 10^{-7}$ & Solomon and Qian (2005) \\
$\mathrm{N}_{2}+h v$ & $\rightarrow \mathrm{N}_{2}^{+}+e$ & $3.62 \times 10^{-7}$ & Solomon and Qian (2005) \\
$\mathrm{N}_{2}+h v$ & $\rightarrow \mathrm{N}^{+}+\mathrm{N}+e$ & $2.78 \times 10^{-8}$ & Solomon and Qian (2005) \\
$\mathrm{O}+h v$ & $\rightarrow \mathrm{O}^{+}+e$ & $2.51 \times 10^{-7}$ & Solomon and Qian (2005) \\
$\mathrm{N}+h v$ & $\rightarrow \mathrm{N}^{+}+e$ & $2.08 \times 10^{-7}$ & Samson and Angel (1990) \\
\hline
\end{tabular}

representing $\mathrm{N}^{+}, \mathrm{NO}^{+}$and $\mathrm{O}^{+}$and their interaction with the neutral atmosphere over a vertically limited domain. Totally, the model chemistry scheme includes 49 neutral species, 5 ions $\left(\mathrm{NO}^{+}, \mathrm{O}^{+}, \mathrm{N}^{+}, \mathrm{N}_{2}^{+}, \mathrm{O}_{2}^{+}\right)$and electrons, and it employs 102 neutral, 27 ion and 49 photolysis reactions. The nitrogen chemistry in the extended CMAM is based on the stratospheric CMAM nitrogen chemistry and expanded. The extended CMAM chemistry no longer treats molecular oxygen and nitrogen as inert fixed fields but advects and introduces chemistry and physics, thus allowing the breakdown of $\mathrm{O}_{2}$ and $\mathrm{N}_{2}$ into $\mathrm{O}, \mathrm{NO}, \mathrm{NO}_{2}$ and $\mathrm{N}$ in the upper atmosphere. The chemistry for molecular oxygen is solved explicitly and combined with the other chemical equations. The atomic nitrogen is no longer solved using photochemical equilibrium but solved as part of the Newton solver with a large number of new $\mathrm{N}$ production and sink terms added, principally resulting from the addition of basic ion chemistry (Tables 1a, b). The ion chemistry is a simple subset without electronically excited states considered that provides a good representation of the MLT region but does not represent the chemistry above the lower thermosphere. One recent change in the extended CMAM is the use of the model in a "nudged" mode, which allows the model to be forced towards re-analysis data (ERA-Interim, ERAI; Dee et al., 2011) to study specific events, such as SSW during particular observation periods. The simplified assimilation system of ERAI data employs a CIN scheme, which is based on the incremental analysis updating methodology (Bloom et al., 1996; Polavarapu et al., 2004) to force the lower atmosphere (ground to $10 \mathrm{hPa}$, $\sim 30 \mathrm{~km}$ ) to the observed state. This allows the upper atmosphere to be driven by a realistic lower atmospheric state in the form of "forecast" mode with an update frequency of $6 \mathrm{~h}$. The CIN scheme is currently used for atmospheric initialization of the coupled forecast models in the Canadian Seasonal to Inter-annual Prediction Scheme (CanSIPS) (Merryfield et al., 2013). With the CMAM-CIN modelling system the specific dates covering the SSW of 2004, 2006 and 2009 can be modelled and compared to daily observations without the need to resort to climatological comparisons.

The mesospheric response to the three recent major SSWs in the winters of 2003/2004, 2005/2006 and 2008/2009 has been the focus of many observational studies. As it will be shown hereafter, although the model was nudged only up to $10 \mathrm{hPa}(\sim 30 \mathrm{~km})$, the extended CMAM-CIN captures
Table 1b. Ion chemistry reactions used in the extended CMAM

\begin{tabular}{lll}
\hline Reaction & Reaction coefficient & Reference \\
\hline $\mathrm{O}_{2}^{+}+\mathrm{NO} \rightarrow \mathrm{NO}^{+}+\mathrm{O}_{2}$ & $4.6 \times 10^{-10}$ & Woodall et al. (2007) \\
$\mathrm{O}_{2}^{+}+\mathrm{N}_{2} \rightarrow \mathrm{NO}^{+}+\mathrm{NO}$ & $5.0 \times 10^{-16}$ & Rees (1989) \\
$\mathrm{O}_{2}^{+}+\mathrm{N} \rightarrow \mathrm{NO}^{+}+\mathrm{O}$ & $1.8 \times 10^{-10}$ & Woodall et al. (2007) \\
$\mathrm{N}_{2}^{+}+\mathrm{O}_{2} \rightarrow \mathrm{O}_{2}^{+}+\mathrm{N}_{2}$ & $5.0 \times 10^{-11}$ & Woodall et al. (2007) \\
$\mathrm{N}_{2}^{+}+\mathrm{NO} \rightarrow \mathrm{NO}^{+}+\mathrm{N}_{2}$ & $4.4 \times 10^{-10}$ & Woodall et al. (2007) \\
$\mathrm{N}_{2}^{+}+\mathrm{O} \rightarrow \mathrm{NO}^{+}+\mathrm{N}$ & $1.3 \times 10^{-10}$ & Woodall et al. (2007) \\
$\mathrm{N}_{2}^{+}+\mathrm{O} \rightarrow \mathrm{O}^{+}+\mathrm{N}_{2}$ & $1.0 \times 10^{-11}$ & Woodall et al. (2007) \\
$\mathrm{N}_{2}^{+}+\mathrm{N} \rightarrow \mathrm{N}^{+}+\mathrm{N}_{2}$ & $1.0 \times 10^{-11}$ & Woodall et al. (2007) \\
$\mathrm{O}^{+}+\mathrm{O}_{2} \rightarrow \mathrm{O}_{2}^{+}+\mathrm{O}$ & $1.9 \times 10^{-11}$ & Woodall et al. (2007) \\
$\mathrm{O}^{+}+\mathrm{N}_{2} \rightarrow \mathrm{NO}^{+}+\mathrm{N}$ & $1.2 \times 10^{-12, *}$ & Woodall et al. (2007) \\
$\mathrm{N}^{+}+\mathrm{O}_{2} \rightarrow \mathrm{NO}^{+}+\mathrm{O}$ & $2.63 \times 10^{-10}$ & Woodall et al. (2007) \\
$\mathrm{N}^{+}+\mathrm{O}_{2} \rightarrow \mathrm{O}^{+}+\mathrm{NO}$ & $3.66 \times 10^{-11}$ & Woodall et al. (2007) \\
$\mathrm{N}^{+}+\mathrm{O}_{2} \rightarrow \mathrm{O}_{2}^{+}+\mathrm{N}$ & $3.11 \times 10^{-10}$ & Woodall et al. (2007) \\
$\mathrm{N}^{+}+\mathrm{NO} \rightarrow \mathrm{NO}^{+}+\mathrm{N}$ & $4.51 \times 10^{-10}$ & Woodall et al. (2007) \\
$\mathrm{N}^{+}+\mathrm{NO} \rightarrow \mathrm{N}_{2}^{+}+\mathrm{O}$ & $7.90 \times 10^{-11}$ & Woodall et al. (2007) \\
$\mathrm{N}^{+}+\mathrm{O} \rightarrow \mathrm{O}^{+}+\mathrm{N}$ & $5.0 \times 10^{-13}$ & Woodall et al. (2007) \\
$e+\mathrm{O}_{2}^{+} \rightarrow 2 \mathrm{O}$ & $1.06 \times 10^{-5} T^{-0.7}$ & Woodall et al. (2007) \\
$e+\mathrm{NO}^{+} \rightarrow \mathrm{N}+\mathrm{O}$ & $3.55 \times 10^{-6} T^{-0.37}$ & Woodall et al. (2007) \\
$e+\mathrm{N}_{2}^{+} \rightarrow 2 \mathrm{~N}$ & $9.41 \times 10^{-7} T^{-0.30}$ & Woodall et al. (2007) \\
$e+\mathrm{O}^{+} \rightarrow \mathrm{O}$ & $1.40 \times 10^{-10} T^{-0.66}$ & Woodall et al. (2007) \\
$e+\mathrm{N}^{+} \rightarrow \mathrm{N}$ & $1.09 \times 10^{-10} T^{-0.58}$ & Woodall et al. (2007) \\
\hline$*>223 \mathrm{~K}$ & &
\end{tabular}

realistically the mesospheric response to these events through the model dynamics and this agreement serves to validate the consistency in the thermospheric dynamical response to SSWs while examining the coupling of the thermosphere with the middle atmosphere.

\section{Results}

\subsection{The winter Arctic middle atmosphere}

Model simulations of temperature, zonal and meridional winds, $\mathrm{NO}_{\mathrm{X}}$ and $\mathrm{CO}$ have been examined for the period from December to March of 2003/2004, 2005/2006 and $2008 / 2009$, over the altitude range from 10 to $200 \mathrm{~km}$ and latitudes from 50 to $85^{\circ} \mathrm{N}$. The evolution of the zonally averaged temperature and the mean zonal wind from 10 to $150 \mathrm{~km}$ height at the time of the major SSW events (observed on 23 December 2003, 21 January 2006 and 23 January 2009, or day of year 360,385 and 387 starting from January 1 of 2003, 2005 and 2008, respectively) is shown in Figs. 13 . Figures 1 and 2 present the temperature evolution at 80 and $65^{\circ} \mathrm{N}$, respectively, while Fig. 3 shows the zonal winds at both 80 and $65^{\circ} \mathrm{N}$ latitude. For each of the three winter seasons of interest, the temperature evolution is presented in two panels. The lower panels show temperature fields in the stratosphere and mesosphere $(10-100 \mathrm{~km})$ expressed in actual values, whereas the upper panels present the temperature evolution in the lower thermosphere $(10-150 \mathrm{~km})$ expressed in terms of temperature residuals (after subtracting values averaged over the considered period, from 1 December to $31 \mathrm{March})$. The use of residual values removes the 
effect of the large vertical temperature gradients throughout the altitude range of the UMLT region. The upper and bottom panels overlap in height at $100-110 \mathrm{~km}$ in order to map corresponding signatures between the two regions, the stratosphere/mesosphere and the lower thermosphere. According to the model results, most pronounced at $80^{\circ} \mathrm{N}$, there was a stratospheric warming event around 23 December 2003 (day of year 355-358, beginning 1 January, Fig. 1b) with zonal mean temperature of $\sim 275 \mathrm{~K}$ at $45 \mathrm{~km}$ height (the stratopause), which was accompanied by cooling of the upper mesosphere from $\sim 75$ to $\sim 100 \mathrm{~km}$ due to adiabatic expansion and vertical advection at the time of the SSW as was first noted by Labitzke (1972), and further discussed by Siskind et al. (2005) and Cho and Shepherd (2006). This mesospheric cold temperature anomaly has a downward phase progression suggesting upwelling at the time of the SSW. An anomalous descent can be seen below $100 \mathrm{~km}$ down to $30 \mathrm{~km}$ around day 360 , with a mesospheric cold temperature anomaly appearing almost simultaneously above the stratospheric warm temperature anomaly associated with the SSW. During the recovery phase, day 365-385 (1-20 January 2004), there was an increase of temperature in the mesosphere around days 375 and 380 (10 and 15 January 2004) associated with the reformation of the stratopause. The stratopause reformed around day 380 at $\sim 70 \mathrm{~km}$, but was colder than prior to the SSW event and remained cold until day 410 (14 February 2004) before descending to about $60 \mathrm{~km}$ for the rest of February 2004. It further warmed up and slowly descended with a rate of $\sim 200 \mathrm{~m} \mathrm{day}^{-1}$, which is considered a normal vortex descent rate. The UMLT region above $90-100 \mathrm{~km}$ height remained undisturbed after day 390 (25 January 2004). This was consistent with experimental results discussed by Manney et al. (2005) and is not observed in the model results for the other two winter seasons considered (Fig. 1c, d, e and f). At the time of the SSW and the mesospheric cold anomaly in late December 2003 and early January 2004 an enhancement in the residual temperature in the lower thermosphere around day 360 (25 December 2003) was observed right above the mesospheric cold anomaly at the beginning of the recovery phase following the stratospheric warming (Fig. 1a). It peaked at $110 \mathrm{~km}$ with $25 \mathrm{~K}$ and extended up to at least $150 \mathrm{~km}$ with residual values of $10 \mathrm{~K}$ throughout the altitude range. A weaker temperature anomaly with a peak of $10 \mathrm{~K}$ at $110 \mathrm{~km}$ was also extended into the lower thermosphere around days 375-380 (10-15 January 2004). At the time of the cool stratopause from days 380 to 410 (15 January to 14 February 2004) a cold thermospheric anomaly settled above $105-110 \mathrm{~km}$ and lasted till the end of February ( day 425$)$.

In 2006 (Fig. 1c, d) a SSW onset occurred around day 375 (10 January 2006). The stratopause broke up, setting off a recovery phase, which continued until day 400-405 (49 February 2006), when the restored stratopause was well into the climatological mesosphere, reaching as high as $75-80 \mathrm{~km}$. Temperatures of $200 \mathrm{~K}$ reached what would be the climatological upper mesosphere and the mesopause region, at $\sim 95 \mathrm{~km}$. The warming of the mesosphere was observed for about 5 days as high as $100 \mathrm{~km}$, destroying the mesopause before the mesosphere and the mesopause gradually returned to their seasonal temperatures by the end of March 2006. The stratopause descended with a rate of $\sim 600 \mathrm{~m} \mathrm{day}^{-1}$ between days 400 and 430 (4 February and 5 March 2004).

The stratospheric warming and the cold mesospheric anomaly in January 2006 (around day 380, 15 January) were accompanied by a thermospheric warming with a peak of $20 \mathrm{~K}$ at $\sim 110 \mathrm{~km}$ (Fig. 1c,d), while the effect of the stratopause recovery phase and the elevated stratopause were accompanied by a cold thermospheric anomaly, which extended up to $150 \mathrm{~km}$ height and lasted till the end of February (about day 420). In 2008/2009 (Fig. 1e, f) an early stratospheric warming was observed around day 340 (the beginning of December 2008), with a brief recovery phase around day 350 before strengthening again with a second major SSW triggered around day 380 (15 January 2009). The stratopause descended to as low as $30 \mathrm{~km}(240 \mathrm{~K}$ contour) on day 385 (20 January 2004), with a warm temperature of $230 \mathrm{~K}$ extending even further down to the lower stratosphere. The recovery phase lasted for about a week, and by day 400 (4 February 2009) the stratopause was reformed at what would normally be considered climatological upper mesosphere at $\sim 90 \mathrm{~km}$, practically destroying the mesosphere, as it was during the SSW 2006. Over the next two months the stratopause gradually returned to its climatological altitude at $50 \mathrm{~km}$.

As in the previous cases, the cold mesospheric anomaly at the time of the January 2009 (around day 390, 25 January) SSW was accompanied by a thermospheric warm anomaly (Fig. 1e) with a peak of $20 \mathrm{~K}$ at $110 \mathrm{~km}$ and extending up to $140 \mathrm{~km}$ height with a value of $10 \mathrm{~K}$. The effect of the elevated and reformed stratopause extended up to $110 \mathrm{~km}$ (Fig. 1f). The cold thermospheric anomaly closely mapped the reformation and the strengthening of the stratopause, with downward descent indicating upwelling with adiabatic cooling at the time of the stratopause descent toward the last stratospheric warming at the end of March. From the three winters the thermosphere in 2006 appeared quieter over the period considered with smaller variations around the average, while 2004 was the most disturbed, with variations of at least $\pm 25 \mathrm{~K}$ from the average from December to March. The thermospheric response to the onset of the SSW and the following recovery phase appeared as cold temperature anomalies, extending in altitude to at least $150 \mathrm{~km}$ into the thermosphere, although the restored stratopause in 2004 was much cooler and lower in peak height than those for either 2006 or 2009.

Because the stratopause reformed very high in altitude, it left very low temperatures between 30 and $50 \mathrm{~km}$, most apparent in 2006 and 2009 (Fig. 1d, f). The effect of the SSWs extended down to $\sim 10 \mathrm{~km}$, while in the UMLT it reached as high as $140 \mathrm{~km}$. The rate of stratopause descent from its 
a) RESidual TEMPERATURE, 80N, DEC 2003 - MAR 2004

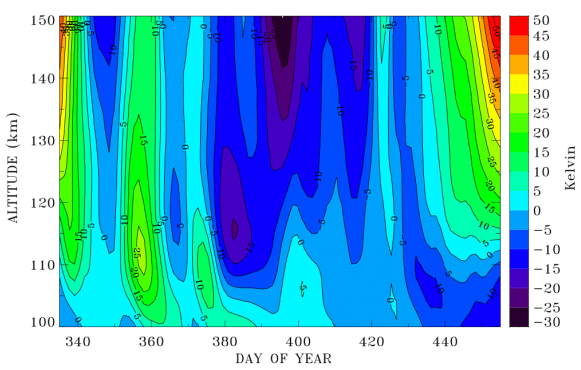

c) RESIDUAL TEMPERATURE, 80N, DEC 2005 - MAR 2006

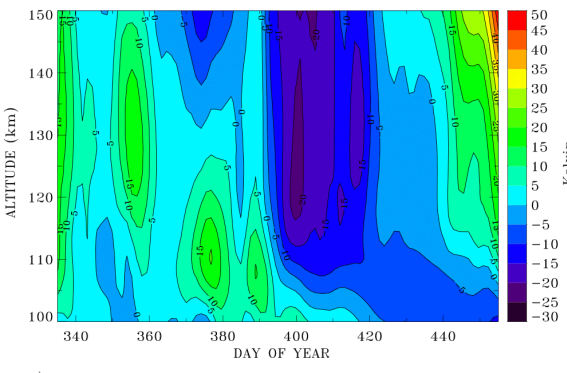

e) RESidual TEMPERATURE, 80N, DEC 2008 - MAR 2009

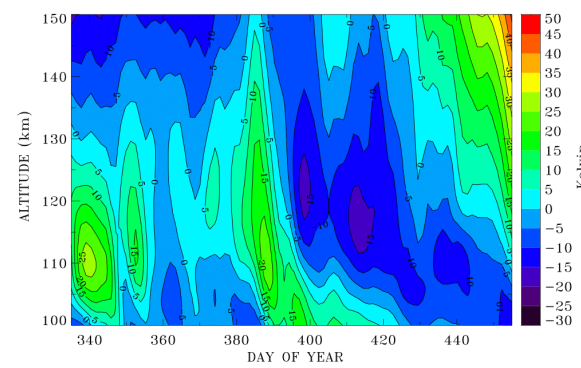

b) ZONAL MEAN TEMPERATURE, 80N, DEC 2003 - MAR 2004

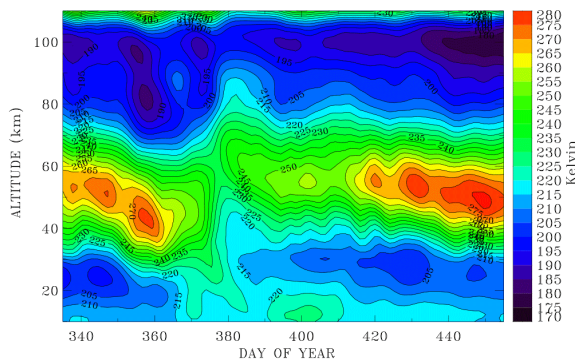

d) ZONAL MEAN TEMPERATURE, 80N, DEC 2005 - MAR 2006

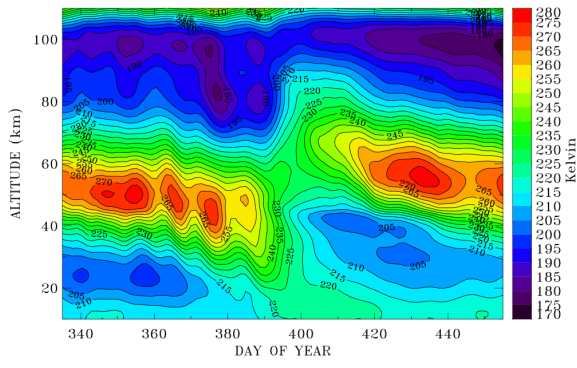

f) ZONAL MEAN TEMPERATURE, 80N, DEC 2008 - MAR 2009

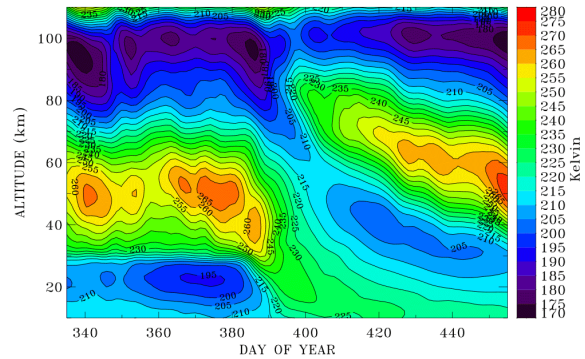

Figure 1. Evolution of the zonal mean temperature at $80^{\circ} \mathrm{N}$ for the period 1 December-31 March (day of year 335-455, starting 1 January 2003 (2005 and 2008, respectively)) for the three SSW events considered. (a, c, e) Temperature residuals (values averaged over 1 December-31 March are subtracted) from 100 to $150 \mathrm{~km}$; (b, d, f) zonal mean temperatures from 10 to $110 \mathrm{~km}$ (5 K contours).

reformation to the climatological height in 2009 was estimated to be $\sim 800 \mathrm{~m} \mathrm{day}^{-1}$.

At $65^{\circ} \mathrm{N}$, the latitude considered by Shepherd and Shepherd (2011) (Fig. 2), the three SSWs could be seen in the stratosphere/mesosphere (Fig. 2b, d, f), but similar to the results at $80^{\circ} \mathrm{N}$ the thermospheric response was strongest in 2003/2004, spanning a range of $50 \mathrm{~K}$, while in 2006 and 2009 it was less perturbed and about a factor of 2 weaker (Fig. 2a, c, e). The recovery phase of the SSW 2004 was short with no elevation of the stratopause during its reformation (Fig. 2b). From the three seasons considered the SSW 2009 recovery phase was the most prolonged with about 20 days of almost isothermal stratosphere/mesosphere temperature variation of $\sim 5-10 \mathrm{~K}$ from 20 to $80 \mathrm{~km}$ (Fig. 2f).

While the altitude of the stratopause prior to the SSW in all three cases was at $\sim 50 \mathrm{~km}$, following the recovery phase it was reformed at an increasing altitude from year to year. For example the $230 \mathrm{~K}$ contour can be seen at 70,80 and $90 \mathrm{~km}$ on day 380 (15 January) in 2004, day 402 (6 February) in 2006 and day 405 (9 February) in 2009, respectively.

The warming seen in the mesosphere/lower thermosphere around $100-120 \mathrm{~km}$ height at the time of the SSW onset is consistent in magnitude with the TIME-GCM/CCM ${ }^{1}$, GAIA $^{2}$ and HAMMONIA ${ }^{3}$ model simulations by Liu and Roble (2002), Liu et al. (2013) and Miller et al. (2013), respectively, and ground-based radar (e.g. Hoffmann et al., 2007; Kurihara et al., 2010) and the MIPAS satellite observations (Funke et al., 2010).

The model zonal mean winds for the three periods of interest at 65 and $80^{\circ} \mathrm{N}$ are shown in Fig. 3. It can be seen that during the three winter seasons of interest the polar vortex

\footnotetext{
${ }^{1}$ Thermosphere, Ionosphere, Mesosphere and Electrodynamics General Circulation Model/Climate Community Model version 3.

${ }^{2}$ Ground-to-topside model of Atmosphere and Ionosphere for Aeronomy.

${ }^{3}$ Hamburg Model of the Neutral and Ionized Atmosphere.
} 
a) RESIDUAL TEMPERATURE, 65N, DEC 2003 - MAR 2004

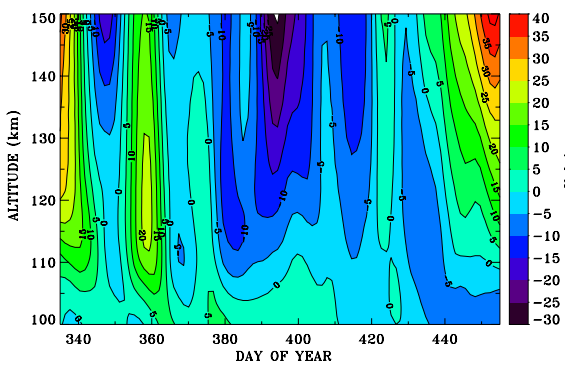

c) RESIDUAL TEMPERATURE, 65N, DEC 2005 - MAR 2006

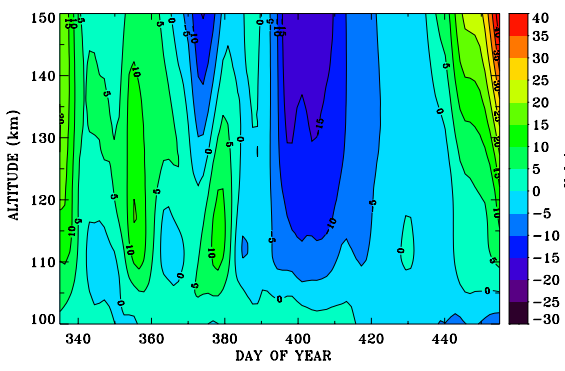

e) RESidUal TEMPERATURE, 65N, DEC 2008 - MAR 2009

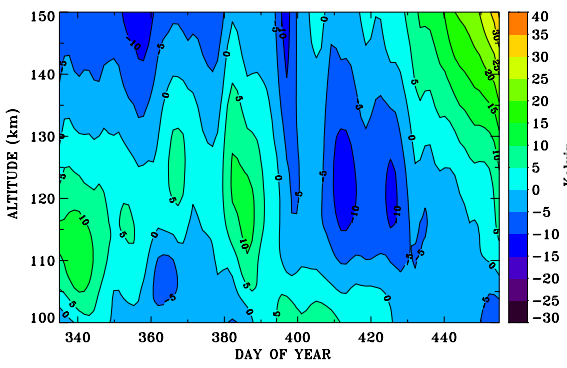

Figure 2. The same as in Fig. 1, but at $65^{\circ} \mathrm{N}$.

winds were by a factor of almost 2 stronger over $65^{\circ} \mathrm{N}$ than at $80^{\circ} \mathrm{N}$. The reversal of the zonal mean wind from eastward direction (positive) to westward direction (negative) in the stratosphere at $65^{\circ} \mathrm{N}$ (Fig. 3a, c, e) marked the beginning of the SSW and was also observed at $80^{\circ} \mathrm{N}$ (Fig. 3b, d, f) albeit with reduced strength.

In December 2003 at $65^{\circ} \mathrm{N}$ and about day 355 (20 December 2003, Fig. 3a) the direction of the zonal wind reversed from eastward to westward in the stratosphere as the vortex broke down, while the mesospheric winds were all westward except for a weak reversal to eastward $\left(\sim 10 \mathrm{~m} \mathrm{~s}^{-1}\right)$ at $\sim 80-100 \mathrm{~km}$ during the SSW recovery phase. The vortex reformed by day 380 (15 January 2004) with a peak at $60 \mathrm{~km}$ at $65^{\circ} \mathrm{N}$ (where the restored stratopause was also observed) and at around $65-70 \mathrm{~km}$ at $80^{\circ} \mathrm{N}$ (Fig. 3b), well into the climatological mesosphere. Except for a brief weakening of the eastward winds around day 390 (25 January 2004) it continued building up with a series of warming pulses throughout February and March 2004 (days 400-440, 5 February15 March 2004) (Fig. 3a), when the wind speed at $65^{\circ} \mathrm{N}$ reached $70-90 \mathrm{~m} \mathrm{~s}^{-1}$. In the UMLT the prevailing wind was b) ZONAL MEAN TEMPERATURE, 65N, DEC 2003 - MAR 2004

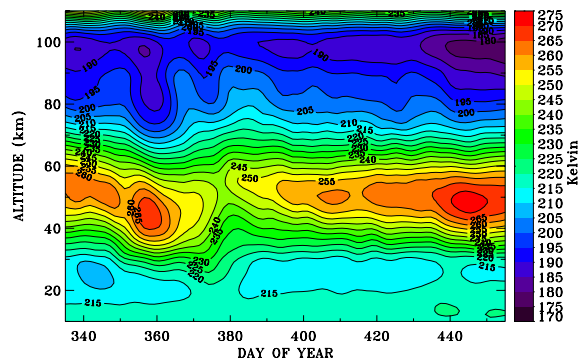

d) ZONAL MEAN TEMPERATURE, 65N, DEC 2005 - MAR 2006

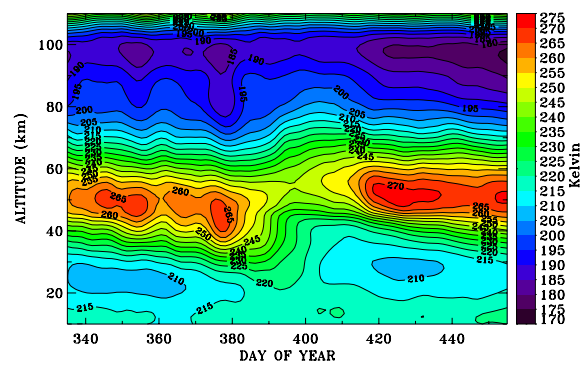

f) ZONAL MEAN TEMPERATURE, 65N, DEC 2008 - MAR 2009

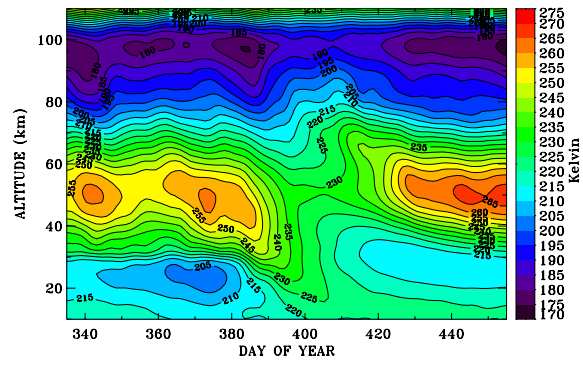

westward with a peak at $100 \mathrm{~km}$. The warming pulses of increased eastward flow in the stratosphere were accompanied by an increase in the westward winds in the UMLT region. The westward winds dominated the recovery phase of the stratopause and extended up to $80 \mathrm{~km}$. They also dominated the $80-120 \mathrm{~km}$ altitude range (the MLT region) both at 65 and $80^{\circ} \mathrm{N}$ except for a brief reversal to eastward winds around days 360-380 (25 December 2003-15 January 2004) during the vortex recovery phase.

In 2006 at $65^{\circ} \mathrm{N}$ (Fig. 3c) the reversal of the zonal mean flow also took place in two pulses, with the first one of westward winds appearing around day 370 (5 January 2006). The polar vortex broke down during the second pulse, and the SSW commenced on day 386 (21 January 2006). The reversed zonal mean westward flow at $65^{\circ} \mathrm{N}$ reached a peak velocity of 55-60 $\mathrm{m} \mathrm{s}^{-1}$ around day 390 (25 January), which did not diminish with latitude and can also be seen at $80^{\circ} \mathrm{N}$ (Fig. 3d), compared to the velocity of 5-10 $\mathrm{m} \mathrm{s}^{-1}$ in 2004 and 2009. While the westward zonal winds continue descending toward the lower stratosphere, in the climatological mesosphere the flow reversed to eastward and the vortex began 
a) ZONAL MEAN ZONAL WIND, 65N, DEC 2003 - MAR 2004

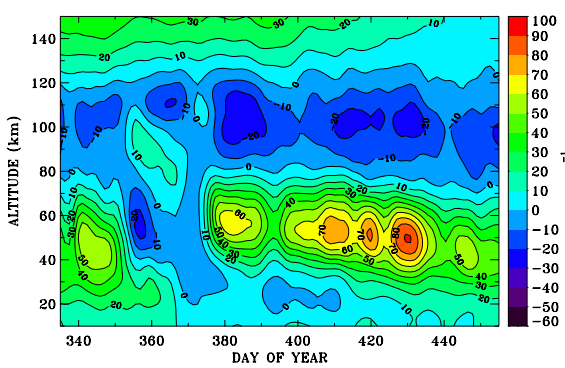

c) ZONAL MEAN ZONAL WIND, 65N, DEC 2005 - MAR 2006

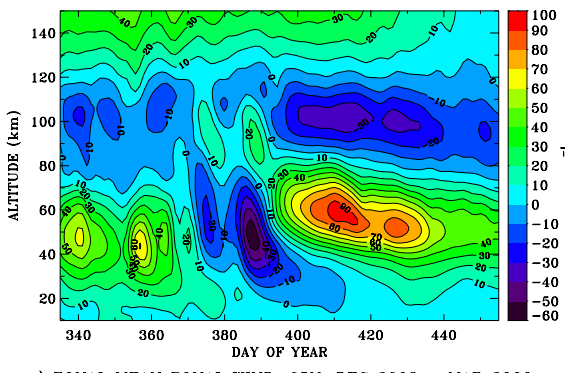

e) ZONAL MEAN ZONAL WIND, 65N, DEC 2008 - MAR 2009

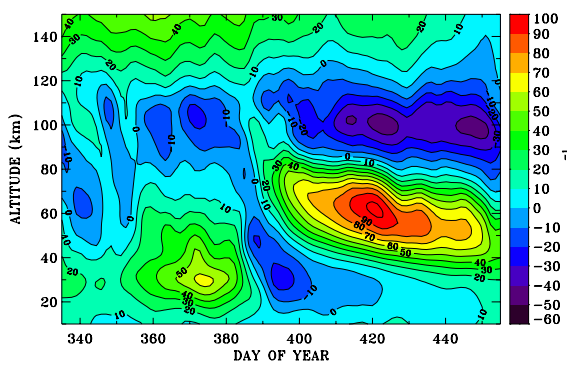

b) ZONAL MEAN ZONAL WIND, 80N, DEC 2003 - MAR 2004

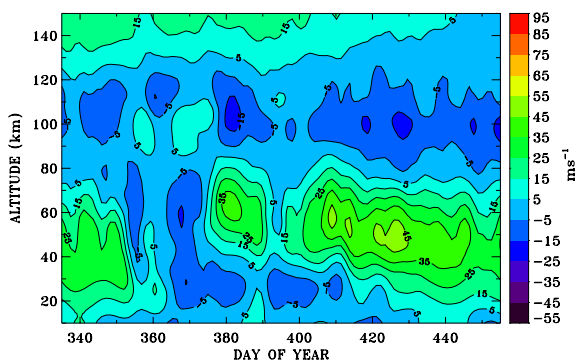

d) ZONAL MEAN ZONAL WIND, 80N, DEC 2005 - MAR 2006

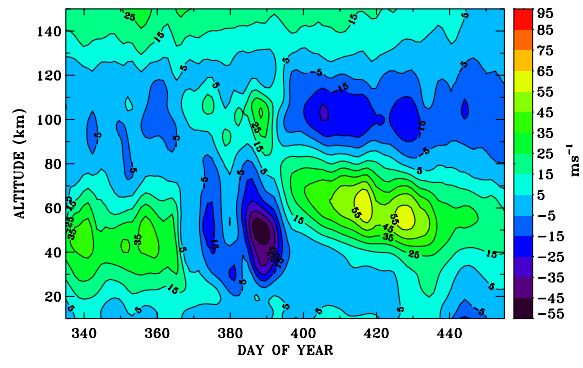

f) ZONAL MEAN ZONAL WIND, 80N, DEC 2008 - MAR 2009

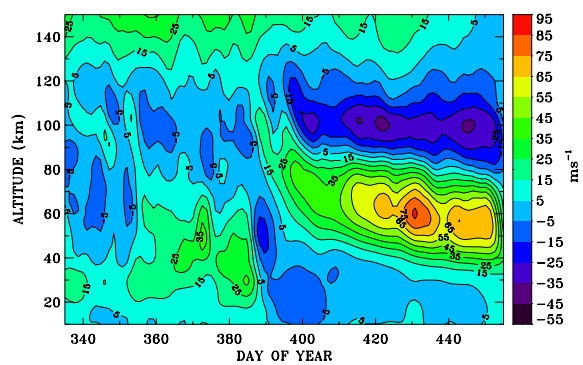

Figure 3. Evolution of the zonal mean wind at $65^{\circ} \mathrm{N}$ (left column) and $80^{\circ} \mathrm{N}$ (right column) for the period 1 December-31 March (day 335 to day 455), for 2003/2004, 2005/2006 and 2008/2009 (10 $\mathrm{m} \mathrm{s}^{-1}$ contours).

reforming and descending. The zonal mean wind field at $80^{\circ} \mathrm{N}$ (Fig. 3d) shows the same pattern, although it is generally weaker in strength. The magnitude of the eastward zonal winds at $80-120 \mathrm{~km}$ height was comparable to that of the vortex at $50 \mathrm{~km}$, prior to the vortex breakdown. The zonal mean flow reversed back to westward in the UMLT after day 395396 (1 February 2006) and remained so until the end of the period considered. The vortex recovery phase at $55 \mathrm{~km}$ lasted from day 370 to day 395 (Fig. 3d). The 2006 vortex continued descending and strengthening as it was reforming, with its upper boundary well into the upper mesosphere, $\sim 80 \mathrm{~km}$, and by the first half of March (day 435, 10 March 2006) its lower edge reached $15 \mathrm{~km}$ height. The vortex was stronger than the one in 2004 with a peak wind velocity of $90 \mathrm{~m} \mathrm{~s}^{-1}$ at $65^{\circ} \mathrm{N}$ and $55 \mathrm{~m} \mathrm{~s}^{-1}$ at $80^{\circ} \mathrm{N}$.

The modelled zonal wind field during the 2005/2006 SSW shown in Fig. $3 \mathrm{c}$ and $\mathrm{d}$ is consistent with the MLS and SABER observations at $70^{\circ} \mathrm{N}$ discussed by Manney et al. (2008b) (their Fig. 3) and the MF and meteor radar observations reported by Hoffmann et al. (2007). Both Manney et al. (2008b) and Hoffmann et al. (2007) reported the onset of the SSW 2006 was preceded by planetary wave 1 amplification, which coincided with the first wind reversal, and larger amplitude of planetary wave 2 at the onset of the SSW, starting the prolonged wind reversal. The short-term reversals of the mesospheric winds were followed by a period of strong eastward winds correlated with enhanced turbulent rates and an increase in the gravity wave activity at $70-85 \mathrm{~km}$ height.

The early winter polar vortex in 2008/2009 (Fig. 3e, f) was very weak both at 65 and $80^{\circ} \mathrm{N}$; in the middle atmosphere at $80^{\circ} \mathrm{N}$ (Fig. 3f) the period until day 350, 15 December 2008, was dominated by westward winds from $50 \mathrm{~km}$ to at least $110 \mathrm{~km}$ in the MLT region. From day 350 to day 385 (15 December 2008-20 January 2009) the vortex was strengthened and the eastward winds reached velocity of $50-60 \mathrm{~m} \mathrm{~s}^{-1}$ at $65^{\circ} \mathrm{N}$ and at $30 \mathrm{~km}$ (Fig. 3e) and $30-35 \mathrm{~m} \mathrm{~s}^{-1}$ at $80^{\circ} \mathrm{N}$ and a peak height of 30-40 km (Fig. 3f) before slowing down and breaking on day 387 (22 January 2009). There was a short recovery phase of about a week, after which the vortex eastward-directed winds reformed at $\sim 100-110 \mathrm{~km}$ before 
beginning to descend over the next two months to $\sim 60 \mathrm{~km}$ with a peak wind velocity of 100 and $85 \mathrm{~m} \mathrm{~s}^{-1}$ at 65 and $80^{\circ} \mathrm{N}$, respectively, in early March in the MLT region. The prevailing westward winds peaked at $\sim 100 \mathrm{~km}$, and their effect seems to extend well into the lower thermosphere. Above $\sim 80 \mathrm{~km}$ to $100-110 \mathrm{~km}$, the prevailing winds were westward for more than a month, leading to low wave activity and enabling the formation of a strong polar vortex which did not break until the end of March. Above 120-130 km the zonal mean winds were all eastward.

With the basic fields of temperature and zonal wind describing the dynamical state of the atmosphere during the three SSW seasons, the SSW effects on the trace gases CO and $\mathrm{NO}_{\mathrm{X}}$ are considered next. Both the temperature and the zonal mean winds predicted by the CMAM-CIN are consistent with the SSW climatology of Liu and Roble (2002).

\section{$3.2 \mathrm{CO}$}

Measurements of carbon monoxide (CO) have become an important tool for examining large-scale mesospheric circulations (Clancy et al., 1984; de Zafra and Muscari, 2004; Grossman et al., 2006) and the vertical motions in the stratosphere and mesosphere (Allen et al., 1999, 2000; Forkman et al., 2005; Clerbaux et al., 2005). In the stratosphere and mesosphere $\mathrm{CO}$ has long been used to infer dynamical processes and diagnose trace gas transport (e.g. Hays and Olivero, 1970; Allen et al., 1981). CO is also used to evaluate the dynamics in three-dimensional models (e.g. Jin et al., 2005, 2009; Minschwaner et al., 2010; Kvissel et al., 2012). During polar night $\mathrm{CO}$ losses are reduced due to the decrease in $\mathrm{OH}$ (from reduced photolysis of $\mathrm{H}_{2} \mathrm{O}$ ), which makes its chemical lifetime much longer. In this case $\mathrm{CO}$ follows the meridional circulation toward the winter hemisphere polar night pole with strong descent at high latitudes through the mesosphere and stratosphere. As a result, the meridional circulation transports high amounts of $\mathrm{CO}$ into these regions, which in turn leads to a sharp CO gradient down to the stratosphere (Solomon et al., 1985), and the downward tilt of the $\mathrm{CO}$ isopleths toward spring time. Due to the photodissociation of $\mathrm{CO}_{2}$ in the UMLT region there is a large reservoir of CO there with a peak at $\sim 110 \mathrm{~km}$, which can be transported down into the mesosphere and stratosphere during periods of strong descent like the one which occurs during stratospheric warming events (Solomon et al., 1985; Allen et al., 2000).

Figure 4 shows the daily zonal mean CO VMR at 65 and $80^{\circ} \mathrm{N}$ for the period of day 335 to day 455 (1 December to $31 \mathrm{March})$ for the three winter seasons considered, 2003/2004, 2005/2006 and 2008/2009 at altitudes from 30 to $90 \mathrm{~km}$. The VMR in ppbv are expressed in terms of $\log _{10}$ due to the large VMR vertical gradient observed from the stratosphere to the thermosphere. It can be seen that on the dates of the onset of the SSW (day 355 (21 December) in 2003/2004, day 378 (13 January) in 2005/2006 and day 385 (20 January) in 2008/2009) the descent of CO into the winter stratosphere due to the meridional circulation is interrupted by uplifting of the CO layer, with $\mathrm{CO}$-poor air entering the lower climatological mesosphere at and above $60 \mathrm{~km}$, followed by descent into the stratosphere, reaching its lowest altitude about 40 days after the SSW event. At $65^{\circ} \mathrm{N}$ (Fig. 4a, c, e) the descent was stronger in 2004 and 2006, reaching down to $50 \mathrm{~km}$ height (e.g. - 0.2 contour), while in 2009 it was quite shallow and comparable to the level prior to the SSW event. At $65^{\circ} \mathrm{N}$ the response of the mesosphere to the SSW was more comparable in 2004 and 2006 than in 2009.

At $80^{\circ} \mathrm{N}$ (Fig. 4b, d, f) the uplifting at the time of the SSW was more pronounced up to $\sim 70 \mathrm{~km}$ in 2004 than in 2006 and 2009. It began at the onset of the SSW and lasted through the recovery phase before the downward funnelling began with the reformation of the elevated stratopause and the reversal of the stratospheric jet back to eastward. A descent of CO followed all three SSW events, reaching the stratosphere within about 40 days after the SSW, with funnelling of the CO down to about $45-50 \mathrm{~km}$ into the stratosphere (e.g. -0.2 contour). Although this funnelling was massive, its lower border exhibited larger variation in its descent, while its temporal extent indicated a connection to the reformation of the polar vortex following the SSW event and the unusually cold stratopause in late January/mid-February 2004, seen in Fig. 1b. In 2004 the recovery phase of the polar vortex at $80^{\circ} \mathrm{N}$ was accompanied by a strong downward flux (to $\sim 55 \mathrm{~km}$ ) around days 375-380 (10-15 January 2004). After the initial descent immediately following the stratopause recovery phase, around days 380-390 (1525 January 2004), no more downward transport appears to take place, but rather the $\mathrm{CO}$ funnel is eroded over time, being subjected to horizontal mixing and loss as the vortex is weak (Fig. 3b) and the advection is decreased (Fig. 4b). The CO flux further descended down to $\sim 45 \mathrm{~km}$ over a period of about a month, while gradually being dissolved by more intense vertical mixing during February (days 396-425) and eventually destroyed in early March due to $\mathrm{CO}$ losses in reaction with $\mathrm{OH}$, formed through $\mathrm{H}_{2} \mathrm{O}$ photodissociation during the polar sunrise. The relatively flat isopleths above $80 \mathrm{~km}$ in the winter mesosphere after day 395 (days 396-455, February/March 2004) indicate that equilibrium between vertical transport and horizontal mixing was established quickly and was maintained.

The period between day 380 and 420 (15 January24 February 2004), when a weak CO downwelling was observed (Fig. 4a, b), coincided with the reforming of the unusually cold stratopause following the SSW recovery phase. Although the stratopause was elevated, it reached only $\sim 70 \mathrm{~km}$. A number of studies have shown that the elevated stratopause is caused by increased gravity wave breaking and the resulting deposition of momentum flux (Hauchecorne et al., 2007; Siskind et al., 2010). The lack of stratopause elevation in January 2004 during the recovery phase, in addition to the cold temperatures observed, suggests a reduction in gravity wave activity occurring during the period. In 2006 the 
a) ZONAL MEAN CO VMR, 65N, DEC 2003 - MAR 2004

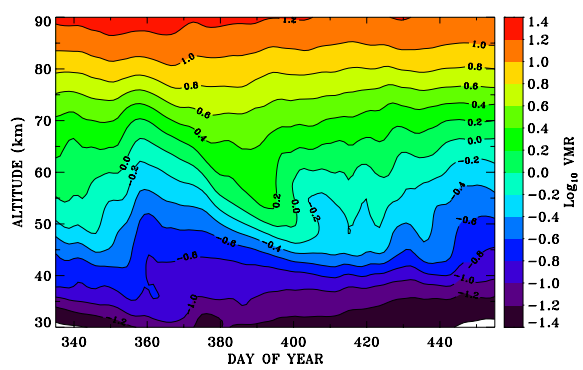

c) ZONAL MEAN CO VMR, 65N, DEC 2005 - MAR 2006

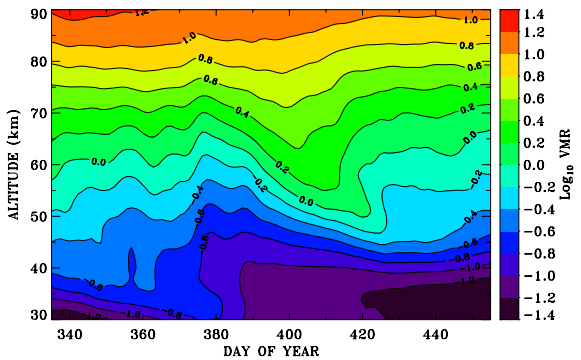

e) ZONAL MEAN CO VMR, 65N, DEC 2008 - MAR 2009

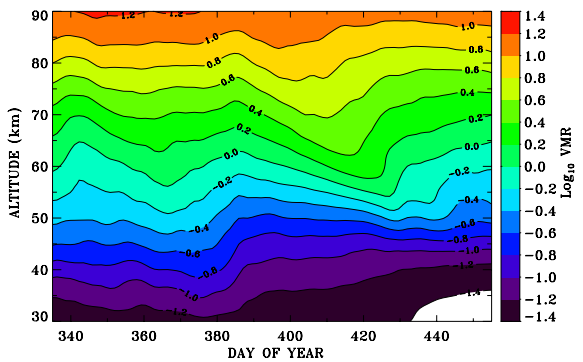

b) ZONAL MEAN CO VMR, 80N, DEC 2003 - MAR 2004

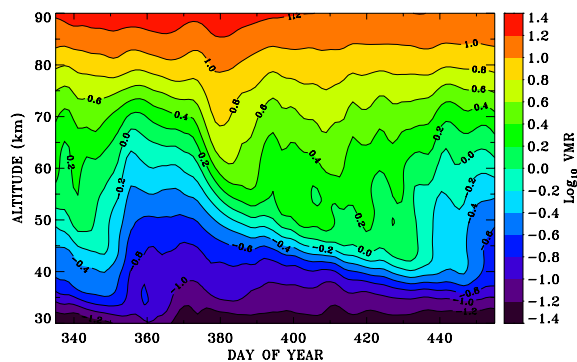

d) ZONAL MEAN CO VMR, 80N, DEC 2005 - MAR 2006

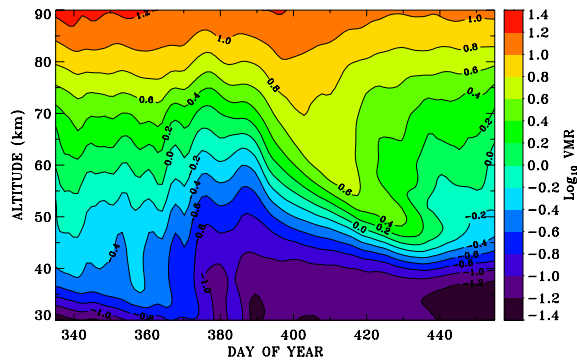

e) ZONAL MEAN CO VMR, 80N, DEC 2008 - MAR 2009

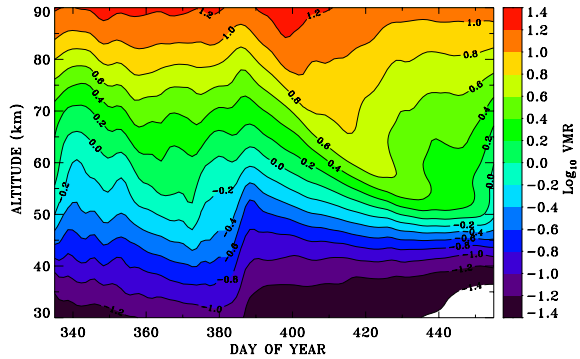

Figure 4. Evolution of the zonal mean $\mathrm{CO}\left(\log _{10}\right.$ of VMR in ppmv) at $65^{\circ} \mathrm{N}$ (left column) and $80^{\circ} \mathrm{N}$ (right column) from $1 \mathrm{December}$ to 31 March (day 335-455) of 2003/2004, 2005/2006 and 2008/2009, for the altitude range 30-90 km.

CO descent appeared massive and very constrained down to $\sim 45 \mathrm{~km}$, with a strong and long-lasting influx coming from well above $90 \mathrm{~km}$ (Fig. 4c, d); it results from the pull of the strong vortex which brings $\mathrm{CO}$ air down to the reformed stratopause, where it is mixed with stratospheric air. In the mesosphere $\mathrm{CO}$ decreased and eventually was destroyed by the polar sunrise, mixing with meridionally transported midlatitude low-CO air, and the last stratospheric warming in late March (Fig. 4d). The pattern is similar for the CO downwelling in the winter of 2009 (Fig. 4e, f) which started around day 400 (5 February 2009) - it was broad and long-lasting, with a large gradient at $\sim 50 \mathrm{~km}$. It dominated the entire range from 50 to $90 \mathrm{~km}$ (and above), with a significant reduction in the middle and upper stratosphere after mid-January due to the SSW; it was slowly destroyed through mixing and $\mathrm{H}_{2} \mathrm{O}$ photodissociation by the end of March. As the recovery phase was short, about a week compared to the 20-25 days in 2004 and 2006, large CO VMRs were still observed in the stratosphere until the end of March 2009.

\section{$3.3 \mathrm{NO}$}

Figure 5 shows the $\mathrm{NO}_{\mathrm{X}}$ VMR between 30 and $90 \mathrm{~km}$ at $65^{\circ} \mathrm{N}$ (Fig. 5a, c, e) and $80^{\circ} \mathrm{N}$ (Fig. 5b, d, f) from day 335 to 455 (1 December-31 March) for the three winter seasons under consideration. As Solomon et al. (1982) and Solomon and Garcia (1983) pointed out, the $\mathrm{NO}_{\mathrm{X}}$ and CO chemistries are very similar, and as in the case of CO VMR, the onset of the $\mathrm{SSW}$ is seen as a decrease of $\mathrm{NO}_{\mathrm{X}}$ around days 355-360 (20-25 December) for 2003/2004, days 375-385 (10-20 January) for 2005/2006 and days 385-395 (20-30 January) for $2008 / 2009$, indicating $\mathrm{NO}_{\mathbf{X}}$-poor air drawn from below into the upper stratosphere and mesosphere. During the recovery phase of the SSW and the reformation of the stratopause and the polar vortex, $\mathrm{NO}_{\mathrm{X}}$-rich air is drawn from the UMLT into the lower mesosphere and stratosphere. This effect is significantly stronger at $80^{\circ} \mathrm{N}$ (Fig. $5 \mathrm{~b}, \mathrm{~d}, \mathrm{f}$ ) than at $65^{\circ} \mathrm{N}$ (Fig. 5a, c, e), showing latitudinal dependence of the $\mathrm{NO}_{\mathrm{X}}$ influx. The $\mathrm{NO}_{\mathrm{X}}$ descent brought high $\mathrm{NO}_{\mathrm{X}}$ VMRs down to the upper stratosphere $(\sim 40 \mathrm{~km})$ and lasted for about two 
a) ZONAL MEAN NOx VMR, 65N, DEC 2003 - MAR 2004

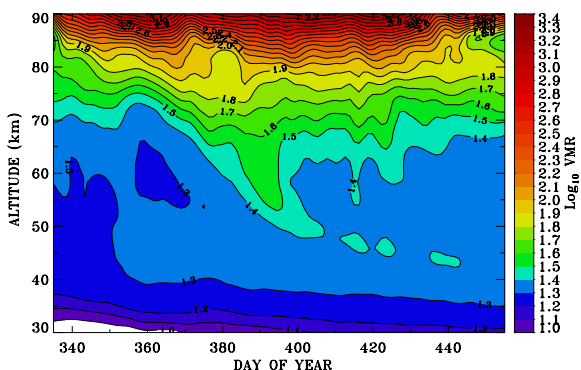

c) ZONAL MEAN NOx VMR, 65N, DEC 2005 - MAR 2006

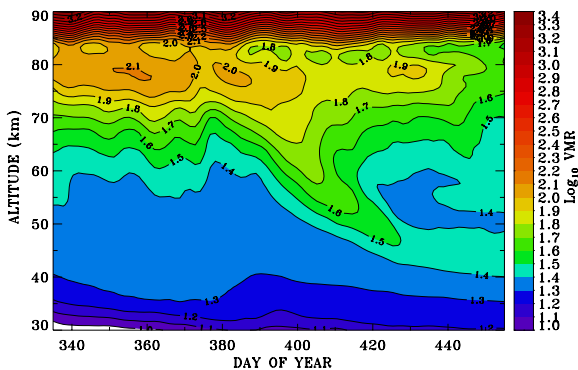

e) ZONAL MEAN NOX VMR, 65N, DEC 2008 - MAR 2009

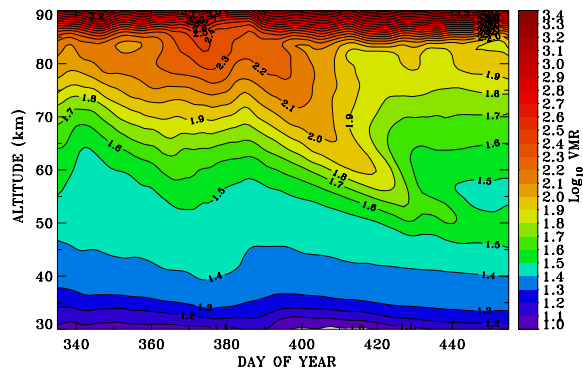

b) ZONAL MEAN NOx VMR, 80N, DEC 2003 - MAR 2004

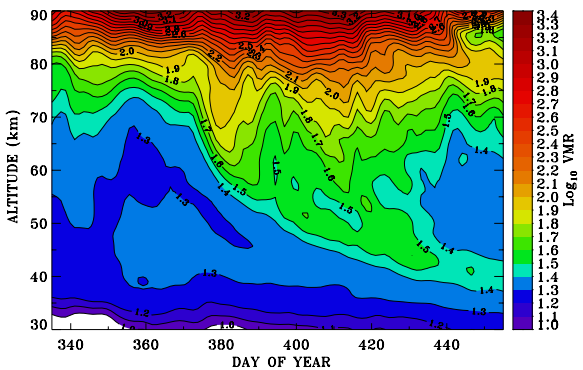

d) ZONAL MEAN NOx VMR, 80N, DEC 2005 - MAR 2006

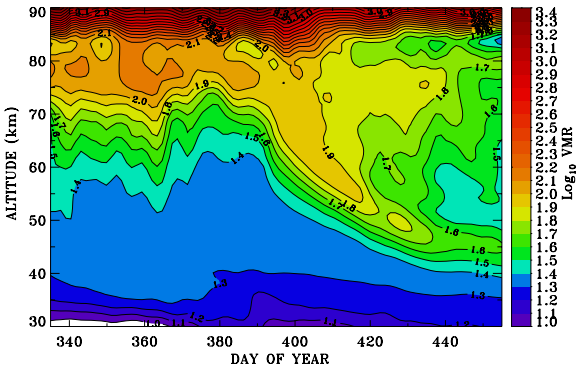

f) ZONAL MEAN NOx VMR, 80N, DEC 2008 - MAR 2009

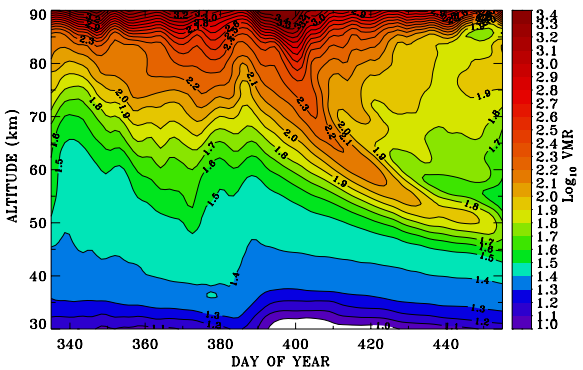

Figure 5. The same as in Fig. 4, but for $\mathrm{NO}_{\mathrm{X}}\left(\mathrm{NO}+\mathrm{NO}_{2}\right)\left(\log _{10}\right.$ of $\mathrm{VMR}$ in ppbv).

months before being destroyed in the upper stratosphere and lower mesosphere through horizontal and vertical mixing and photolysis by sunlight resulting from the polar sunrise.

An increased vertical and horizontal mixing is most apparent at $80^{\circ} \mathrm{N}$ in 2004 (Fig. 5b), with an influx around day 380, after which the $\mathrm{NO}_{\mathrm{X}} \mathrm{VMR}$ was rapidly mixed and remained at about the same level over the next 40 days, before being destroyed by mid-March. There is a prolonged descent of $\mathrm{NO}_{\mathrm{X}}$ from the UMLT region down to about 75$80 \mathrm{~km}$ following the influx on day 380 (15 January 2004), but it did not penetrate further down into the lower mesosphere and stratosphere. This is well correlated with the reformed cool stratopause around day 375-385 at $\sim 65-70 \mathrm{~km}$ (see Fig. 1b), which remained cold until $\sim$ day 420 (end of February), while $\mathrm{NO}_{\mathrm{X}}$ was transported further down below the climatological stratopause. The mesosphere appeared to be very perturbed with high amounts of $\mathrm{NO}_{\mathrm{X}}$ down to $\sim 70$ $75 \mathrm{~km}$ until the end of the period, but the $\mathrm{NO}_{\mathrm{X}}$ loss was not so great in spite of the photolysis that came with the polar sunrise. Another difference between the SSWs in 2004 and those in 2006 and 2009 was the time of the SSW event - it was in December 2003, while in 2006 and 2009 the SSWs were in the second half of January. Thus by the end of the polar night and polar sunrise in mid-February 2004 the $\mathrm{NO}_{\mathrm{X}}$ was much more mixed and diluted than in the other two SSW seasons.

The effect of the $2006 \mathrm{SSW}$ on the $\mathrm{NO}_{\mathrm{X}}$ layer (Fig. 5c, d) is different from that observed in 2004. A large amount of $\mathrm{NO}_{\mathrm{X}}$ was observed in the mesosphere down to $\sim 75 \mathrm{~km}$ with a peak around days 355-360 (20-25 December 2005), which preceded the warming of the stratosphere. During the SSW 2006 recovery phase this $\mathrm{NO}_{\mathrm{X}}$ was drawn into the upper stratosphere, reaching $\sim 45 \mathrm{~km}$ by early March 2006 (day 430). At the same time in the mesosphere at $80^{\circ} \mathrm{N}$ the $\mathrm{NO}_{\mathrm{X}}$ was gradually destroyed as could be observed above $85 \mathrm{~km}$ with large VMR gradient. $\mathrm{NO}_{\mathrm{X}}$ VMRs of 5063 ppbv (1.7-1.8 $\left.\log _{10} \mathrm{VMR}\right)$ were observed down to $45 \mathrm{~km}$, compared to $20 \mathrm{ppbv}\left(1.3 \log _{10}\right.$ VMR) observed in February/March 2004. The pattern of the downwelling of $\mathrm{NO}_{\mathrm{X}}$ seemed to combine the broad penetration of $\mathrm{NO}_{\mathrm{X}}$ into the 
upper mesosphere in 2004, with a strong funnelling into the lower stratosphere as observed in 2006. In 2009 (Fig. 5e, f) the $\mathrm{NO}_{\mathrm{X}}$ descent from the UMLT region into the lower mesosphere and stratosphere was the most pronounced among the three SSW events and reached $50 \mathrm{~km}$ at $80^{\circ} \mathrm{N}$ by day 450 (March equinox, 2009) with a $\mathrm{NO}_{\mathrm{X}} \mathrm{VMR}$ of $50 \mathrm{ppbv}$ $\left(1.7 \log _{10}\right.$ VMR), while in the upper stratosphere and lower mesosphere it was slowly destroyed.

To put into perspective the CMAM-CIN $\mathrm{NO}_{\mathrm{X}}$ results with respect to the observations by the ACE-FTS satellite experiment (Bernath et al., 2005), previously reported by Randall et al. (2009) and Manney et al. (2009), the model daily zonally averaged $\mathrm{NO}_{X}$ VMRs were sampled in the ACE-FTS format (according to the latitude of the ACE-FTS daily solar occultations; see also Randall et al., 2009, their Fig. 1) for the three winter seasons of interest for days of year 1 to 90 from 1 January to 31 March, and are shown in Fig. 6. The ACE-FTS measurements are in the regime of solar occultation and represent almost the same latitudes from year to year. The $\mathrm{NO}_{\mathrm{X}} \log _{10} \mathrm{VMRs}$ from 1 to 3 corresponding to 10 to $1000 \mathrm{ppbv}$ are shown between 30 and $90 \mathrm{~km}$ height, to allow for direct comparison between the three winter seasons. The contour for $\mathrm{NO}_{\mathrm{X}} \log _{10} \mathrm{VMR}$ of 1.5 is used as a reference for the comparisons. The decrease of $\mathrm{NO}_{X} \mathrm{VMR}$ with increasing height around day 40 (10 February) is due to the change in direction of the ACE-FTS instrument observation toward low latitudes, which is seen as a decrease in the $\mathrm{NO}_{\mathrm{X}} \mathrm{VMR}$. Around mid-February, day 40 (15 February), the ACE-FTS continued observations at northern high latitudes and the observed $\mathrm{NO}_{\mathrm{X}}$ VMR increased.

In 2004 (Fig. 6a) the downward funnelling of $\mathrm{NO}_{\mathrm{X}}$ is first observed on about 25 January 2004 (day 25), when enhanced $\mathrm{NO}_{\mathrm{X}}$ reaches $\sim 50 \mathrm{~km}$ height, but briefly receded back to $70 \mathrm{~km}$ before descending to $45 \mathrm{~km}$ for most of February. The descent of the $\mathrm{NO}_{\mathrm{X}}$ is relatively weak and shortlived, and values of $1.5 \log _{10}$ VMR (32 ppbv) dominate the lower mesosphere/upper stratosphere and were rapidly destroyed by vertical mixing at the upper boundary of the polar vortex and through photodissociation during polar sunrise in late February and early March. Most of the enhanced $\mathrm{NO}_{\mathrm{X}}$ remained in the UMLT region with perturbed isopleths above $80 \mathrm{~km}$ (Fig. 6a). The $\mathrm{NO}_{\mathrm{X}}$ (as the CO) mixing following the 2003/2004 SSW was correlated with the time of the cold stratopause (Fig. 1b). In 2004 ACE-FTS NOX observations were available only after about day 50 (19 February) and showed high $\mathrm{NO}_{\mathrm{X}} \mathrm{VMR}$ of about $200 \mathrm{ppbv}\left(2.3 \log _{10}\right.$ VMR) reaching $50 \mathrm{~km}$ and lasting until the first half of March (e.g. Randall et al., 2009, Fig. 1), compared to modelled 3240 ppbv (1.5-1.6 $\left.\log _{10} \mathrm{VMR}\right)$ at the same altitude of $50 \mathrm{~km}$, or a factor of $\sim 5$ smaller than the observations. This underestimation can be, at least partially, explained by the missing energetic particle precipitation production of $\mathrm{NO}_{X}$ in the model simulations. This $\mathrm{NO}_{\mathrm{X}}$ enhancement continued into the stratosphere up until Northern Hemisphere equinox, decreasing in magnitude to $50-20 \mathrm{ppbv}\left(1.7-1.3 \log _{10} \mathrm{VMR}\right)$

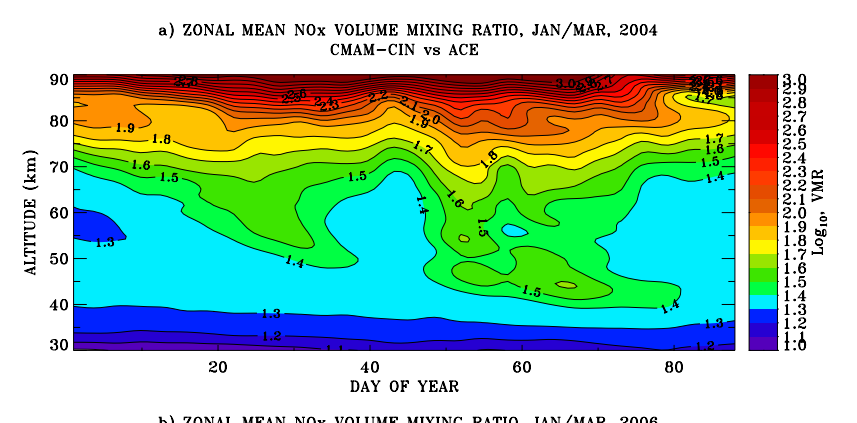

b) ZONAL MEAN NOX VOLUME MIXING RATIO, JAN/MAR, 2006 CMAM-CIN vs ACE

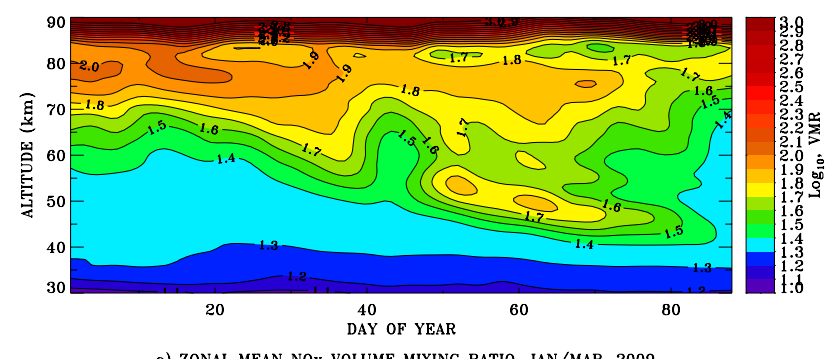

c) ZONAL MEAN NOx VOLUME MIXING RATIO, JAN/MAR, 2009

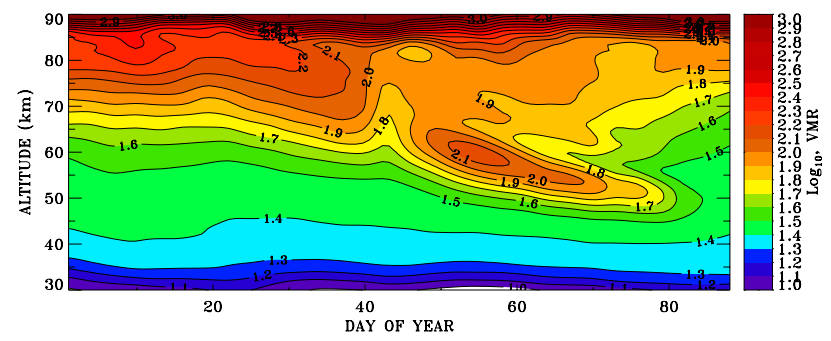

Figure 6. Evolution of the zonal mean $\mathrm{NO}_{\mathrm{X}}\left(\mathrm{NO}+\mathrm{NO}_{2}\right) \log _{10}$ VMRs in ppbv sampled in the ACE-FTS observing format as a function of day of year and altitude, from 1 January to 31 March (day 1-90) in (a) 2004, (b) 2006 and (c) 2009.

before being mixed and destroyed. This compares with 1.5$1.4 \log _{10}$ VMR as simulated by the model (Fig. 6a).

In 2006 (Fig. 6b) the $\mathrm{NO}_{\mathrm{X}}$ descended down to $55-45 \mathrm{~km}$ in the second part of February and remained there for most of March, while in the lower mesosphere, around $60 \mathrm{~km}$, it started decreasing. In the "tongue", seen down to $\sim 40 \mathrm{~km}$ after day 50 (19 February), the two maxima in the extended CMAM-CIN are of 1.7-1.8 $\log _{10}$ VMR (50-63 ppbv), while the peaks in the ACE-FTS observations are $\sim 2 \log _{10}$ VMR (100 ppbv) at about $60 \mathrm{~km}$ and descend down to $50 \mathrm{~km}$ with a $1.7 \log _{10}$ VMR (50 ppbv) by March equinox, when the model estimates are of the order of $1.5 \log _{10}$ VMR $(32 \mathrm{ppbv})$; thus the CMAM-CIN predictions in the upper stratosphere/lower mesosphere are by about 30-35\% smaller than the ACE-FTS observations in the upper stratosphere. The mesosphere in January 2009 (Fig. 6c) experienced massive influx of $\mathrm{NO}_{\mathrm{X}}$ from the thermosphere with VMRs of the order of $125 \mathrm{ppbv}$ $\left(2.1 \log _{10} \mathrm{VMR}\right)$ and higher above $75 \mathrm{~km}$. The $1.5 \log _{10}$ VMR (32 ppbv) isopleth reached $\sim 50 \mathrm{~km}$. The $\mathrm{NO}_{\mathrm{X}}$ funnel most pronounced after day 50 (19 February 2009) was 
very broad and intense, and although there was no further influx from above, high amounts of $\mathrm{NO}_{\mathrm{X}}\left(1.9-2.1 \log _{10} \mathrm{VMR}\right.$ or $79-125 \mathrm{ppbv}$ ) remained present in the lower mesosphere and upper stratosphere even during sunrise. The difference between the modelled and observed $\mathrm{NO}_{\mathrm{X}}$ in 2009 is of the order of 30-35\%.

Since the CMAM-CIN model does not account for EPP as the source of thermospheric $\mathrm{NO}_{X}$, the results shown in Fig. 6 give only the $\mathrm{NO}_{X}$ resulting from meteorological conditions and dynamic perturbations associated with the nudging of the basic fields below $10 \mathrm{hPa}(\sim 30 \mathrm{~km})$. In spite of the model underestimation of the $\mathrm{NO}_{X}$ VMR by 30-35\% particularly for 2006 and 2009 the model adequately represents the dynamics of the mesosphere and, since the latter is not vertically constrained, of the lower thermosphere above. This is also supported by available observations as discussed in Sect. 4.

Figure 7 shows the $\mathrm{NO}_{\mathrm{X}}$ vertical distribution from 30 to $150 \mathrm{~km}$ for the three winter seasons at $80^{\circ} \mathrm{N}$ and day 335 to 455 (1 December-31 March). Now that the dynamic effects on the $\mathrm{NO}_{\mathrm{X}} \mathrm{VMR}$ have been confirmed in the stratosphere and mesosphere particularly in the comparison with the 2006 observations, the effect of the SSW on the UMLT region up to about $150 \mathrm{~km}$ and during the three SSW events is further examined. Once again, the picture outlined by the variations of the $\mathrm{NO}_{X}$ VMR in Fig. 7 is that caused only by SSW dynamical effects on the altitude region up to $150 \mathrm{~km}$.

In the mesosphere there is a weak descent below $65 \mathrm{~km}$, which in 2004 (Fig. 7a) reached down to $45 \mathrm{~km}$ with $\mathrm{NO}_{\mathrm{X}}$ $\log _{10}$ VMR of 1.5 (32 ppbv), while the $\mathrm{NO}_{\mathrm{X}} \log _{10} \mathrm{VMR}$ of 1.9 (79 ppbv) did not descend further than $70 \mathrm{~km}$. In 2006 the $\mathrm{NO}_{\mathrm{X}} \log _{10} \mathrm{VMR}$ of 1.9 reached $65 \mathrm{~km}$ in late February (Fig. 7b), while in 2009 (Fig. 7c) this level of VMR was maintained at $50 \mathrm{~km}$ well until mid-March. While the funnelling effect is observed mostly below $90 \mathrm{~km}$ in 2006 and 2009 (Fig. 7b, c), the atmosphere above appeared well mixed, except for downwelling of $\mathrm{NO}_{X}$ at the time of the $\mathrm{NO}_{X}$ descent (days 390-400, 25 January-5 February) and could be seen in the isopleths, which are decreasing in their height.

Another interesting difference between the state of the UMLT region in 2003/2004, on one hand, and that in 2005/2006 and 2008/2009 on the other is the fact that in the later case all isopleths with values between 2 and $\log _{10}$ VMR (100-10000 ppbv) were more or less horizontal and confined between 85 and $95 \mathrm{~km}$ height, while in 2003/2004 they were perturbed and expanded from 80 to $110 \mathrm{~km}$. The lower thermosphere appeared compressed, with large $\mathrm{NO}_{\mathrm{X}} \log _{10}$ VMR of 5.1 (126 ppmv) descending down to $120 \mathrm{~km}$ and even higher values of $5.3(\sim 200 \mathrm{ppmv})$ from 120 to $140 \mathrm{~km}$ at the time of the beginning of $\mathrm{NO}_{\mathrm{X}}$ descent around day 380 (15 January 2004). Such large $\mathrm{NO}_{X}$ VMRs are observed only toward the end of March with the polar sunrise and at altitudes above $\sim 145-150 \mathrm{~km}$, during the winters of 2006 and 2009. Further, while in 2005/2006 and 2008/2009 the VMR vertical gradient was steep and increased with height toward spring (end of March), in 2004 the period from mid-February a) ZONAL MEAN NOx VMR, 80N, DEC 2003 - MAR 2004

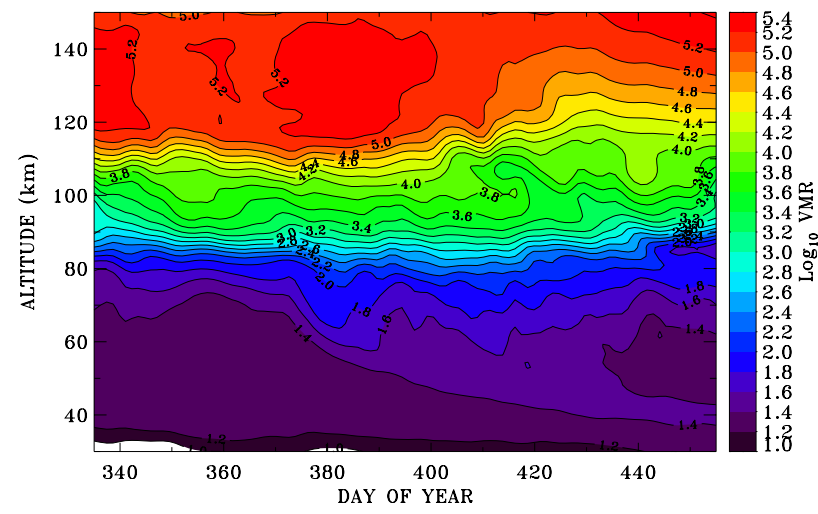

b) ZONAL MEAN NOx VMR, 80N, DEC 2005 - MAR 2006

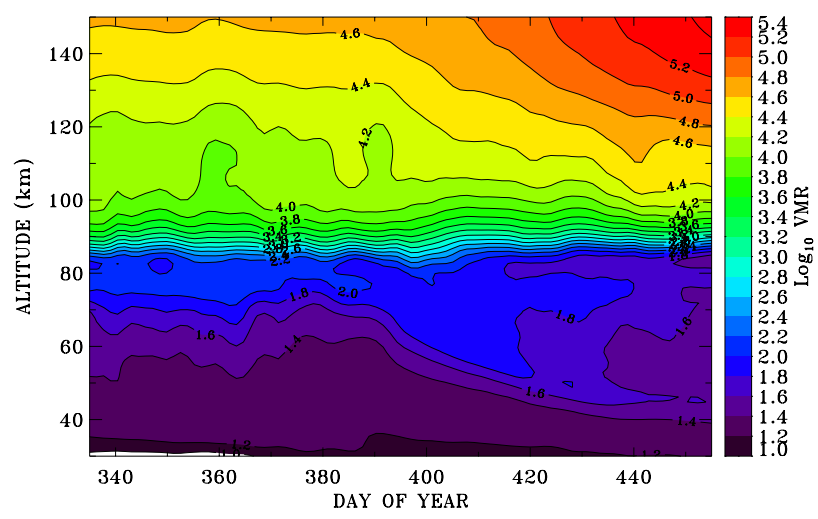

c) ZONAL MEAN NOx VMR, 80N, DEC 2008 - MAR 2009

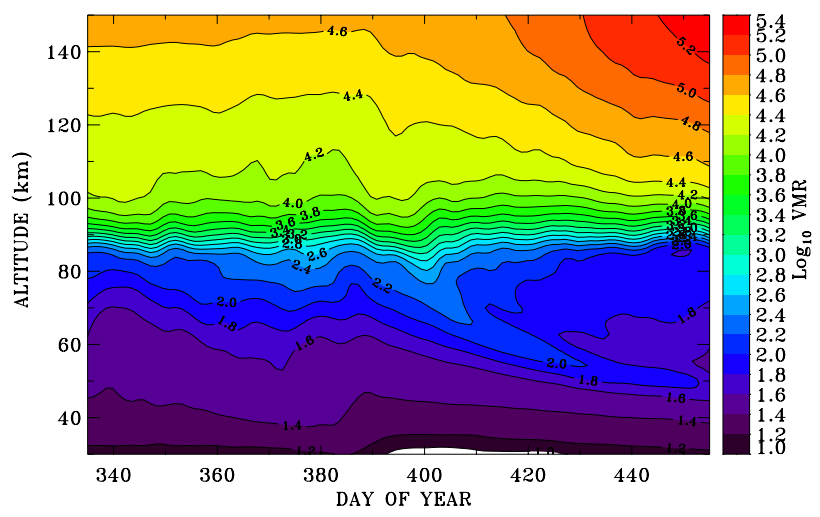

Figure 7. Evolution of the zonal mean $\mathrm{NO}_{\mathrm{X}}\left(\mathrm{NO}+\mathrm{NO}_{2}, \log _{10}\right.$ of VMR in ppbv) at $80^{\circ} \mathrm{N}$ for the altitude range from 30 to $150 \mathrm{~km}$ and from 1 December to 31 March (day 335-455) in (a) 2003/2004, (b) 2005/2006 and (c) 2008/2009.

to mid-March (day 410 to 440 ) indicated $\mathrm{NO}_{\mathrm{X}}$ losses extending to $130-140 \mathrm{~km}$ height.

Figure 7a also shows that the lower thermosphere is significantly perturbed with erosion of the $\mathrm{NO}_{\mathrm{X}}$ by the end of February and March (after day 420, in the second half of 
February) with a decrease of the $\mathrm{NO}_{\mathrm{X}}$ VMR in the lower thermosphere, above $\sim 85-90 \mathrm{~km}$ (where the isopleths are almost flat) at the time when intense $\mathrm{NO}_{\mathrm{X}}$ mixing and loss take place in the lower mesosphere following the polar sunrise (also Fig. 5a, b). The $\mathrm{NO}_{\mathrm{X}}$ appeared depleted, lifting the isopleths from the nominal altitude of $\sim 120 \mathrm{~km}$ to $140 \mathrm{~km}$. Above, the $\mathrm{NO}_{\mathrm{X}}$ follows its seasonal variability with a maximum around $160 \mathrm{~km}$ (not shown). In 2006 and 2009 (Fig. 7b and c) the picture is quite different. There is a large $\mathrm{NO}_{\mathrm{X}}$ gradient between 85 and $95-100 \mathrm{~km}$, with almost horizontal isopleths indicating equilibrium between vertical mixing and horizontal transport with very small variation and almost no effect of polar sunrise and $\mathrm{NO}_{\mathrm{X}}$ loss above $110 \mathrm{~km}$. Prior to the $\mathrm{NO}_{\mathrm{X}}$ downwelling around day 390-400 (26 January4 February 2006) there is a decrease of the $\mathrm{NO}_{\mathrm{X}}$ above $90 \mathrm{~km}$ (to $\sim 120 \mathrm{~km}$ ), suggesting that in the lower thermosphere an upwelling was taking place carrying into the thermosphere air relatively poor of $\mathrm{NO}_{\mathrm{X}}$ compared to the ambient atmosphere. This is an extension of the same signature shown and discussed in Fig. 4 for $\mathrm{CO}$ and Fig. 5 for $\mathrm{NO}_{\mathrm{X}}$. At $120 \mathrm{~km}$ the $\mathrm{NO}_{\mathrm{X}}$ VMR in 2006 was 10 times smaller than that in 2004 for the same period and altitude: only $12.6 \mathrm{ppmv}$ (4.1 $\log _{10}$ VMR) in 2006 and 126 ppmv (5.1 $\log _{10}$ VMR) in 2004. The 2009 SSW was the strongest among the three SSW events considered in terms of the magnitude of temperature change and wind shear. In the thermosphere there was a brief upwelling above $\sim 100 \mathrm{~km}$ around days 383-385 (17-20 January) at the time of the SSW followed by a massive $\mathrm{NO}_{\mathrm{X}}$ downwelling beginning around day 390 (25 January), which is seen to affect the $\mathrm{NO}_{\mathrm{X}}$ field up to at least $130 \mathrm{~km}$, as is outlined by the isopleths of 4.3-4.5 $\log _{10}$ VMR (Fig. 7c).

\section{Discussion}

Many authors have reported an enhancement of $\mathrm{NO}_{\mathrm{X}}$ in the mesosphere and stratosphere following the major stratospheric warmings in January 2004, 2006 and 2009 (Manney et al., 2005, 2009; Randall et al., 2006, 2009; Degenstein et al., 2005; Hauchecorne et al., 2007). Randall et al. (2009) showed that $\mathrm{NO}_{X}$ increased by a factor of $50 \mathrm{com}-$ pared to winters without descent events. Siskind and Russell (1996) and Siskind et al. (1997) investigated NO distribution up to $120 \mathrm{~km}$ from Halogen Occultation Experiment (HALOE)/UARS and showed that there was a transport of auroral NO into the upper stratosphere/mesosphere, which was interpreted as caused by the breaking of planetary waves at middle and low latitudes.

Natarajan et al. (2004) and Rinsland et al. (2005) suggested that a massive EPP event in October/November 2003 was responsible for the observed increase in $\mathrm{NO}_{\mathrm{X}}$ in the upper stratosphere/mesosphere in January 2004, but Randall et al. (2005) argued that this EPP could not be responsible for the increased $\mathrm{NO}_{\mathrm{X}}$ observed in January in the upper stratosphere/mesosphere because the SSW in December would have led to the dilution of the EPP $\mathrm{NO}_{\mathrm{X}}$ with midlatitude air.

López-Puertas et al. (2005) (also Funke et al., 2007) analysed MIPAS observations of $\mathrm{NO}_{2}$ over the period of October 2003 and April 2004 and concluded in agreement with Randall et al. (2005) that the observed enhancement in upper stratospheric $\mathrm{NO}_{2}$ in mid-January 2004 was most probably caused by an unusually strong, compared to previous years, vortex and downward transport together with uncommon auroral activity over the entire winter 2003/2004 season. Clilverd et al. (2007) were the first to provide ionospheric evidence of thermospheric-to-stratospheric descent of polar $\mathrm{NO}_{\mathrm{X}}$. They observed an enhanced descent of $\mathrm{NO}_{\mathrm{X}}$ in the mesosphere at $65-90 \mathrm{~km}$ starting on day 378 (13 January 2004), a month before being seen in the stratosphere. Although there was a geomagnetic storm on day 387-388 (22-23 January 2004) GOMOS/Envisat observations indicated the storm did not create any observable effect on the $\mathrm{NO}_{2}$ (and thus $\mathrm{NO}_{\mathrm{X}}$ ) in the upper stratosphere/lower mesosphere $(50-70 \mathrm{~km})$. However, the GOMOS data showed a significant amount of $\mathrm{NO}_{2}$ below $70 \mathrm{~km}$ produced by a geomagnetic storm on day 407-408 (11-12 February 2004), which contributed to the body of $\mathrm{NO}_{2}$ descending into the stratosphere (Clilverd et al., 2007). This additional source of $\mathrm{NO}_{\mathrm{X}}$ is not captured in the CMAM-CIN model results shown in Figs. 5a and b and 7a since, as was already stated, the model does not account for the effect of EPP on the production of $\mathrm{NO}_{\mathrm{X}}$. Clilverd et al. (2007) also concluded that the start date of the $\mathrm{NO}_{\mathrm{X}}$ descent was not associated with any geomagnetic event, but that the formation of strong polar vortex giving rise to strong downward vertical transport from the pre-existing $\mathrm{NO}_{\mathrm{X}}$ thermospheric reservoir generated by LEPP (auroral low-energy particle precipitation, 1-10 keV) was more plausible.

Hauchecorne et al. (2007) reported an increase of $\mathrm{NO}_{2}$ in the polar UMLT during mid-January/February 2004 observed in solar occultation data from the GOMOS/Envisat satellite experiment in the second half of January and in February 2004. The descent started around day 375 (10 January), about 2 weeks before the geomagnetic storm observed on days 387-390 (22-25 January 2004), which was considered by Renard et al. (2006) to be the source of the observed descending $\mathrm{NO}_{\mathrm{X}}$. Similar to Randall et al. (2006), Hauchecorne et al. (2007) also concluded that the enhancement was the result of the strengthened polar vortex rather than the EPP event prior to the December 2003-March 2004 season. Therefore the erosion of the $\mathrm{NO}_{\mathrm{X}}$ funnel below 65$70 \mathrm{~km}$ reflects only dynamic effects from below. In the second half of February and early March (days 415-430) the gradual destruction of $\mathrm{NO}_{\mathrm{X}}$ was caused by the polar sunrise and the partial destruction through photodissociation of $\mathrm{NO}_{2}$.

Clilverd et al. (2007) also concluded that only during winters with both high geomagnetic activity and strong downward vertical transport would the transport of large amounts of $\mathrm{NO}_{\mathrm{X}}$ down to the stratosphere be facilitated. Both of these 
conditions were fulfilled in 2003/2004, but not in 2005/2006 when no solar proton events or enhanced ionization were observed. This explains the very good agreement between the CMAM-CIN model results for 2006 shown in Fig. 5c and $\mathrm{d}$ and the ACE-FTS observations as reported by Randall et al. (2006). A similar argument applies to the CMAM-CIN 2009 results in Fig. 5e and f.

Most of the modelling of the vertical transport and the downward funnelling of the $\mathrm{CO}$ and $\mathrm{NO}_{\mathrm{X}}$ into the lower mesosphere and stratosphere has been concentrated on the altitude range below $80-90 \mathrm{~km}$ using the European Centre for Medium-Range Weather Forecast (ECMWF) model nudged at $75-80 \mathrm{~km}$ height to the ACE-FTS observations (Salmi et al., 2011), the regular CMAM without nudging with a lid at $95 \mathrm{~km}$ (Jin et al., 2009), the NOGAPS-ALPHA ${ }^{4}$ (Siskind et al., 2010) and recent versions of the CMAM-DAS (Data Assimilation System) and the new CMAM20 relaxation scheme (Ren et al., 2011; McLandress et al., 2013).

Salmi et al. (2011) used the ECMWF and the Fin ROSE chemistry transport models to simulate the winter and strong descent of $\mathrm{NO}_{\mathrm{X}}$ and were able to produce a realistic $\mathrm{NO}_{\mathrm{X}}$ transport in the mesosphere while assuming $\mathrm{NO}_{\mathrm{X}}$ transport from above as observed by the ACE-FTS. The $\mathrm{NO}_{\mathrm{X}}$ model was constrained to time-dependent upper boundary conditions based on the ACE-FTS observations between 75 and $85 \mathrm{~km}$. The ECMWF was used up to $80 \mathrm{~km}$, so the authors were able to study the $\mathrm{NO}_{\mathrm{X}}$ descent starting from the upper mesosphere. However, since the upper boundary of the ECMWF was at $80 \mathrm{~km}$ it could not give any information on the dynamics and transport in the UMLT region. Nezlin et al. (2009) have shown that processes from the troposphere and stratosphere can impact large-scale dynamics in the mesosphere, through upward-propagating resolved waves (Sankey et al., 2007) or through parameterized waves (Ren et al., 2008). Thus, since the SSW is forced by upwardpropagating waves (Matsuno, 1971) the assimilation of observations from the troposphere/stratosphere may be sufficient to describe the large-scale mesospheric response; thus, the CMAM-DAS (Ren et al., 2011) and the CMAM20 simulations (McLandress et al., 2013) were nudged below $1 \mathrm{hPa}$ to SABER/TIMED observations and the ERA-Interim, respectively, with the latter using relaxation up to $1 \mathrm{hPa}$.

While experimental and model results have provided insight on the dynamic effects of SSW on the middle atmosphere and vertical transport in the stratosphere/mesosphere up to $\sim 100 \mathrm{~km}$, the effect of SSW on the thermosphere is still not well known. A number of experimental results during the winter of 2008/2009 have shown perturbations in the neutral and ion temperature and winds (e.g. Goncharenko and Zhang, 2008; Conde and Nicholls, 2010; Funke et al., 2010; Kurihara et al., 2010), coinciding with the onset of the major stratospheric warming event of January and

\footnotetext{
${ }^{4}$ The Navy Operational Global Atmospheric Prediction SystemAdvanced Level Physics-High Altitude
}

February 2009. Therefore the modelling efforts have been extended into the upper atmosphere to examine the dynamical coupling between middle and upper atmosphere.

A model study by Liu and Roble (2002) employing the self-consistent TIME-GCM/CCM3 has examined the SSW impact on the MLT region, showing that at the time of SSW a warming of the lower thermosphere of the order of $20 \mathrm{~K}$ also occurs resulting from secondary downward circulation induced by equatorward mesospheric circulation. A similar warming of the lower thermosphere at the time of SSW is also produced by the CMAM-CIN. The CMAM-CIN thermospheric residual temperatures (Figs. 1 and 2), together with the zonal winds shown in Fig. 3, agree well with the results of Liu and Roble (2002). In addition, the CMAM-CIN temperatures for the SSW in January 2009 at $80^{\circ} \mathrm{N}$ agree well with the MIPAS temperature data averaged over 70$90^{\circ} \mathrm{N}$ during the same period both in structure and magnitude, giving a warm residual temperature anomaly of $25 \mathrm{~K}$ with a peak at $\sim 110 \mathrm{~km}$ and extending up to $\sim 145 \mathrm{~km}$ with a value of $10 \mathrm{~K}$ around day 385-390 (20-25 January 2009) compared to the MIPAS residual temperatures of 15-20 K maximizing at $\sim 120-130 \mathrm{~km}$ (Funke et al., 2010).

The whole atmosphere model GAIA has also been used to examine the atmospheric response to the 2009 major stratospheric warming from the ground to exobase. Liu et al. (2013) found that at northern high latitudes warming of $20 \mathrm{~K}$ occurs at all local times and altitudes of $110-130 \mathrm{~km}$, in agreement with the seminal model study of Liu and Roble (2002) and the results presented herein. Further the GAIA simulations show a general cooling of the thermosphere global mean temperature above about $130 \mathrm{~km}$ extending to as high as $400 \mathrm{~km}$ following the onset of the SSW, which is also well seen in the CMAM-CIM results for the three SSWs (Figs. 1 and 2). These agreements give further support to the CMAM-CIN realistic representation of the basic fields and dynamics of the UMLT region and its coupling with the atmosphere below.

According to Liu and Roble (2002) planetary wave forcing is responsible for variations in the residual circulation in the stratosphere and lower mesosphere, while the residual circulation variability in the MLT region results from variability in the GW forcing. It was shown that eastward gravity waves can penetrate into the mesosphere/lower thermosphere region during the deceleration and reversal of the stratospheric eastward wind at the time of the SSW and induce equatorward/upward circulation between 90 and $105 \mathrm{~km}$, causing adiabatic cooling in the upper mesosphere and poleward/downward circulation above with warming in the thermosphere. Thus, the warm thermospheric residual temperature anomalies in Figs. 1 and 2 from 100 to $150 \mathrm{~km}$ at the time of the SSW onset indicate vertical descent of $\mathrm{NO}_{\mathrm{X}}$ from the thermosphere into the upper mesosphere. However, the altitude of the GW breaking and the deposition of energy and momentum in the model depend on the setting of the chosen GW parameterization scheme and on specification of 
the GW source at the lower boundary. Thus the choice of the non-orographic gravity wave drag (nGWD) parameterization considered, can lead to possible variability in the modelled atmosphere in the wave breaking altitudes (Liu and Roble, 2002).

Model simulations of a major SSW were also conducted employing the Whole Atmosphere Community Climate Model v3.5 (WACCM; Kvissel et al., 2012) to examine the transport of $\mathrm{CO}$ and ozone from the mesosphere into the stratosphere. The model was able to successfully reproduce various characteristics of the middle atmosphere associated with the SSW, including perturbations in the circulation and chemistry of the stratosphere and the mesosphere. This was the first detailed case study of SSW in a comprehensive free-running chemistry-climate model. Similar to the result herein it was shown that during the high-altitude stratopause reformation a mesospheric intrusion with high $\mathrm{CO}$ abundance unfolds and gets cut off from the atmosphere above, being surrounded by stratospheric air poor in $\mathrm{CO}$. This $\mathrm{CO}$ funnel is further propagated downward and meridionally to midlatitudes over a period of 2-3 weeks before being completely diluted in the ambient air.

The role of planetary and gravity waves was also examined with the WACCM for the same major SSW case by Limpasuvan et al. (2012), who showed that the reversal of the zonal mean wind to westward at the time of the SSW onset leads to changes in the zonal-mean wave forcing. Following the SSW recovery planetary waves (both eastward and westward) were identified below the restored stratopause; eastward planetary waves can penetrate the restored stratopause, while no gravity waves were observed below it.

The CMAM-CIN simulations on the $\mathrm{CO}$ and $\mathrm{NO}_{\mathrm{X}}$ transport shown in Figs. 4 and 5 are consistent with the WACCM results reported by Kvissel et al. (2012). The study by Limpasuvan et al. (2012) also gives support to the suggested possible role of planetary waves penetrating through the restored stratopause and propagating throughout the mesosphere and into the lower thermosphere as the source of the dynamic perturbations seen in 2004 and Fig. 7a.

The CMAM-CIN used nudging to the ERAI only up to $10 \mathrm{hPa}$ and was run free up to $200 \mathrm{~km}$ (for low solar activity) employing the Hines (1997) nGWD parameterization scheme. However, the agreement with other assimilation schemes both in magnitude and in the depiction of the height of the elevated stratopause and the polar vortex is found to be very good. As Siskind et al. (2010), Ren et al. (2011) and McLandress et al. (2013) have shown, nGWD is important in simulating the elevated stratopause following the SSW and for capturing the descent of mesospheric constituents. For example, Ren et al. (2011) have shown that the depiction of $\mathrm{NO}_{\mathrm{X}}$ descent was sensitive to the use of nGWD and together with McLandress et al. (2013) demonstrated the importance of realistic depiction of gravity wave drag in the data assimilation schemes.
The results presented have shown that the CMAM-CIN is able to capture both the magnitude and the dynamics of the basic fields and the strong polar vortex during the three SSW below $90-100 \mathrm{~km}$ height. The model has also captured the evolution of the trace gases' descent into the stratosphere following the SSWs and was found to be in good agreement with the ACE-FTS observations for 2006, when the observed downwelling was assigned to dynamics and the strong polar vortex. Since the model does not consider EPP, the predicted $\mathrm{NO}_{\mathrm{X}}$ in 2004, 2006 and 2009 should be considered as resulting only from dynamical transport and responding to the planetary and gravity waves propagating from below. In that regard the 2004 SSW shows the most dynamically perturbed mesosphere/lower thermosphere region from all three SSW events. The SSWs exert effects on the thermospheric neutral temperature at least up to $150 \mathrm{~km}$, which amounts to $\sim 50$ to $60 \mathrm{~K}$ departures in temperature from its zonal mean values.

\section{Summary and conclusions}

The results presented have shown that the extended CMAMCIN model is able to capture the magnitude and the dynamics of the vertical transport not only in the stratosphere and mesosphere, but also in the lower thermosphere (shown here up to $150 \mathrm{~km}$ ), in part due to the more complete and extensive chemistry domain and physics representation used, which extends across and well above the UMLT region. This enables a better representation of the upper atmospheric chemistry and $\mathrm{NO}_{\mathrm{X}}$ in particular.

The fact that, despite missing the EPP effects in this version of the CMAM, the model predictions for the January 2006 SSW were in such good agreement with the experimental $\mathrm{NO}_{\mathrm{X}}$ and $\mathrm{CO}$ data in the mesosphere and stratosphere is consistent with the conclusion of Randall et al. (2009) that the observed funnelling of $\mathrm{NO}_{\mathrm{X}}$ into the stratosphere was more dynamically driven rather than due to EPP.

The extended CMAM-CIN simulations for 2003/2004, $2005 / 2006$ and 2008/2009 appear to well represent the dynamics of the MLT region and the coupling between the thermosphere and the stratosphere through the $\mathrm{NO}_{\mathrm{X}}$ and $\mathrm{CO}$ transport. The good agreement between the extended CMAM-CIN NO ${ }_{X}$ with the 2006 experimental data observed by ACE-FTS served to validate the model results and allowed examining the dynamical effects of stratospheric warmings on the upper mesosphere and lower thermosphere. Both $\mathrm{CO}$ and $\mathrm{NO}_{\mathrm{X}}$ exhibit a distinct latitudinal structure with the main descent close to the pole, which highlights the importance of the vortex re-establishment following the warming and the consequent funnelling of the upper atmosphere chemical fields downward within the polar vortex. The descent increased close to the pole.

The comparisons showed that the extended CMAM-CIN can provide uniquely useful ancillary data to help interpret observations taken during SSW events throughout the middle 
atmosphere and the lower thermosphere. Most operational analyses do not have sufficiently high-altitude model lids and associated local physics and chemistry to capture the mesospheric response (Manney et al., 2008a), and only few of them include chemical fields simulated across and above the MLT region.

Acknowledgements. SRB and VIF would like to thank the Canadian Space Agency for support through the CMAM20 project.

Topical Editor C. Jacobi thanks two anonymous referees for their help in evaluating this paper.

\section{References}

Allen, D. R., Stanford, J. L., López-Valverde, M. A., Nakamura, N., Lary, D. J., Douglass, A. R., Cerniglia, M. C., Remedios, J. J., and Taylor, F. W.: Observations of middle atmosphere CO from the UARS ISAMS during the early northern winter 1991/1992, J. Atmos. Sci., 56, 563-583, 1999.

Allen, D. R., Stanford, J. L., Nakamura, N., López-Valverde, M. A., López-Puertas, M., Taylor, F. W., and Remedios, J. J.: Antarctic polar descent and planetary wave activity observed in ISAMS CO from April to July 1992, Geophys. Res. Lett., 27, 665-668, doi:10.1029/1999GL010888, 2000.

Allen, M., Yung, Y. L., Waters, J. W., Hack, W., Preuss, A. W., Wagner, H. G., and Hoyermann, K.: Vertical transport and photochemistry in the terrestrial mesosphere and lower thermosphere (50-120 km), J. Geophys. Res., 86, 3617-327, 1981.

Andrews, D. G., Holton, J. R., and Leovy, C. B.: Middle Atmosphere Dynamics, Acad. Press, 490 pp., 1987.

Barth, C. A.: Nitric Oxide in the Lower Thermosphere, Planet. Space Sci., 40, 315-336, 1992.

Barth, C. A., Bailey, S. M., and Solomon, S. C.: Solar-terrestrial coupling: Solar soft X-rays and thermospheric nitric oxide, Geophys. Res. Lett., 26, 1251-1254, 1999.

Barth, C. A., Mankoff, K. D., Bailey, S. M., and Solomon, S. C.: Global observations of nitric oxide in the thermosphere, J. Geophys. Res., 108, 1027, doi:10.1029/2002JA009458, 2003.

Beagley, S. R., de Grandpre, J., Koshyk, J. N., McFarlane, N. A., and Shepherd, T. G.: Radiative-dynamical climatology of the first-generation Canadian middle atmosphere model, Atmos. Ocean, 35, 293-331, 1997.

Beagley, S. R., McLandress, C., Fomichev, V. I., and Ward, W. E.: The extended Canadian middle atmosphere model, Geophys. Res. Lett., 27, 2529-2532, 2000.

Beagley, S. R., Boone, C. D., Fomichev, V. I., Jin, J. J., Semeniuk, K., McConnell, J. C., and Bernath, P. F.: First multi-year occultation observations of $\mathrm{CO}_{2}$ in the MLT by ACE satellite: observations and analysis using the extended CMAM, Atmos. Chem. Phys., 10, 1133-1153, doi:10.5194/acp-10-1133-2010, 2010.

Bernath, P. F., McElroy, C. T., Abrams, M. C., Boone, C. D., Butler, M., Camy-Peyret, C., Carleer, M., Clerbaux, C., Coheur, P.-F., Colin, R., DeCola, P., DeMazière, M., Drummond, J. R., Dufour, D., Evans, W. F. J., Fast, H., Fussen, D., Gilbert, K., Jennings, D. E., Llewellyn, E. J., Lowe, R. P., Mahieu, E., McConnell, J. C., McHugh, M., McLeod, S. D., Michaud, R., Midwinter, C., Nassar, R., Nichitiu, F., Nowlan, C., Rinsland, C. P., Rochon, Y. J., Rowlands, N., Semeniuk, K., Simon, P., Skelton, R., Sloan, J. J.,
Soucy, M.-A., Strong, K., Tremblay, P., Turnbull, D., Walker, K. A., Walkty, I., Wardle, D. A., Wehrle, V., Zander, R., and Zou, J.: Atmospheric Chemistry Experiment (ACE), Mission overview, Geophys. Res. Lett., 32, L15S01, doi:10.1029/2005GL022386, 2005.

Bloom, S. C., Takacs, L. L., DaSilva, A. M., and Ledvina, D.: Data assimilation using incremental analysis updates, Mon. Weather Rev., 124, 1256-1271, doi:10.1175/15200493(1996)124<1256:DAUIAU>2.0.CO;2, 1996.

Brasseur, G. P. and Solomon, S.: Aeronomy of the middle atmosphere, Chemistry and Physics of the Stratosphere and Mesosphere Series: Atmospheric and Oceanographic Sciences Library, Vol. 32, Springer, 2005.

Conde, M. G. and Nicolls, M. J.: Thermospheric temperature above Poker Flat, Alaska, during the stratospheric warming event of January and February 2009, J. Geophys. Res., 115, D00N05, doi:10.1029/2010JD014280, 2010.

Cho, Y.-M. and Shepherd, G. G.: Correlation of airglow temperature and emission rate at Resolute Bay $\left(74.68^{\circ} \mathrm{N}\right)$, over four winters (2001-2005), Geophys. Res. Lett., 33, L06815, doi:10.1029/2005GL025298, 2006.

Clancy, R. T., Muhlemah, D. O., and Allen, M.: Seasonal variability of CO in the terrestrial mesosphere, J. Geophys. Res., 89, 96739676, 1984.

Clerbaux, C., Coheur, P.-F., Hurtmans, D., Barret, B., Carleer, M., Colin, R., Semeniuk, K., McConnell, J. C., Boone, C., and Bernath, P.: Carbon monoxide distribution from the ACEFTS solar occultation measurements, Geophys. Res. Lett., 32, L16S01 doi:10.1029/2005GL022394, 2005.

Clilverd, M. A., Seppälä, A., Rodger, C. J., Thomson, N. R., Lichtenberger, J., and Steinbach, P.: Temporal variability of the descent of high-altitude $\mathrm{NO}_{X}$ inferred from ionospheric data, J. Geophys. Res., 112, A09307, doi:10.1029/2006JA012085, 2007.

Dee, D. P., Uppala, S. M., Simmons, A. J., Berrisford, P., Poli, P., Kobayashi, S., Andrae, U., Balmaseda, M. A., Balsamo, G., Bauer, P., Bechtold, P., Beljaars, A. C. M., van de Berg, L., Bidlot, J., Bormann, N., Delsol, C., Dragani, R., Fuentes, M., Geer, A. J., Haimberger, L., Healy, S. B., Hersbach, H., Hólm, E. V., Isaksen, L., Kållberg, P., Köhler, M., Matricardi, M., McNally, A. P., Monge-Sanz, B. M., Morcrette, J.-J., Park, B. K., Peubey, C., de Rosnay, P., Tavolato, C., Thépaut, J.-N., and Vitart, F.: The ERA interim reanalysis: Configuration and performance of the data assimilation system, Q. J. Roy. Meteorol. Soc., 137, 553597, 2011.

Degenstein, D. A., Lloyd, N. D., Bourassa, A. E., Gattinger, R. L., and Llewellyn, E. J.: Observations of mesospheric ozone depletion during the October 28, 2003 solar proton event by OSIRIS, Geophys. Res. Lett., 32, L03S11, doi:10.1029/2004GL021521, 2005.

de Zafra, R. L. and Muscari, G.: CO as an important high-altitude tracer of dynamics in the polar stratosphere and mesosphere, J. Geophys. Res., 109, D06105, doi:10.1029/2003JD004099, 2004.

Fomichev, V. I., Ward, W. E., Beagley, S. R., McLandress, C., McConnell, J. C., McFarlane, N. A., and Shepherd, T. G.: Extended Canadian Middle Atmosphere Model: Zonal-mean climatology and physical parameterizations, J. Geophys. Res., 107, 4087, doi:10.1029/2001JD000479, 2002.

Forkman, P., Eriksson, P., Murtagh, D., and Espy, P.: Observing the vertical branch of the mesospheric circulation at latitude $60^{\circ} \mathrm{N}$ 
using ground-based measurements of $\mathrm{CO}$ and $\mathrm{H}_{2} \mathrm{O}$, J. Geophys. Res., 110, D05107, doi:10.1029/2004JD004916, 2005.

Funke, B., López-Puertas, M., Gil-López, S., von Clarmann, T., Suntiler, G. P., Fischer, H., and Kellmann, S.: Downward transport of upper atmospheric $\mathrm{NO}_{\mathrm{X}}$ into the polar stratosphere and lower mesosphere during the Antarctic 2003 and Arctic 2002/2003 winters, J. Geophys. Res., 110, D24308, doi:10.1029/2005JD006463, 2005.

Funke, B., López-Puertas, M., Fischer, H., Stiller, G. P., von Clarmann, T., Wetzel, G., Carli, B., and Belotti, C.: Comment on "Origin of the January-April 2004 increase in stratospheric $\mathrm{NO}_{2}$ observed in northern polar latitudes" by J.-B. Renard et al., Geophys. Res. Lett., 34, L07813, doi:10.1029/2006GL027518, 2007.

Funke, B., López-Puertas, M., Bermejo-Pantaleón, D., GarcíaComas, M., Stiller, G. P., von Clarmann, T., Kiefer, M., and Linden, A.: Evidence for dynamical coupling from the lower atmosphere to the thermosphere during a major stratospheric warming, Geophys. Res. Lett., 37, L13803, doi:10.1029/2010GL043619, 2010.

Goncharenko, L. and Zhang, S.-R.: Ionospheric signatures of sudden stratospheric warming: Ion temperature at middle latitude, Geophys. Res. Lett., 35, L21103, doi:10.1029/2008GL035684, 2008.

Grossman, K. U., Gusev, O., and Knieling, P.: The distribution of carbon monoxide in the upper mesosphere and lower thermosphere during CRISTA-1 and -2, J. Atmos. Sol.-Terr. Phys., 68, 1764-1780, 2006.

Hauchecorne, A., Bertaux, J.-L., Dalaudier, F., Russell III, J. M., Mlynczak, M. G., Kyrölä, E., and Fussen, D.: Large increase of $\mathrm{NO}_{2}$ in the north polar mesosphere in January-February 2004: Evidence of a dynamical origin from GOMOS/ENVISAT and SABER/TIMED data, Geophys. Res. Lett., 34, L03810, doi:10.1029/2006GL027628, 2007.

Hays, P. B. and Olivero, J. J.: Carbon dioxide and monoxide above the troposphere, Planet. Space Sci., 18, 1729-1733, 1970.

Hines, C. O.: Doppler-spread parameterization of gravity-wave momentum deposition in the middle atmosphere. Part I: Basic formulation, J. Atmos. Sol.-Terr. Phys., 59, 371-386, 1997.

Hoffmann, P. W., Singer, D., Keuger, W. K., Hocking, M., Kunze, and Murayama, Y.: Latitudinal and longitudinal variability of mesospheric winds and temperatures during stratospheric warming events, J. Atmos. Sol.-Terr. Phys., 69, 2355-2366, doi:10.1016/j.jastp.2007.06.010, 2007.

Jin, J. J., Semeniuk, K., Jonsson, A. I., Beagley, S. R., McConnell, J. C., Boone, C. D., Walker, K. A., Bernath, P. F., Rinsland, C. P., Dupuy, E., Ricaud, P., De La Noë, J., Urban, J., and Murtagh, D.: Co-located ACE-FTS and Odin/SMR stratospheric-mesospheric CO 2004 measurements and comparison with a GCM, Geophys. Res. Lett., 32, L15S03, doi:10.1029/2005GL022433, 2005.

Jin, J. J., Semeniuk, K., Beagley, S. R., Fomichev, V. I., Jonsson, A. I., McConnell, J. C., Urban, J., Murtagh, D., Manney, G. L., Boone, C. D., Bernath, P. F., Walker, K. A., Barret, B., Ricaud, P., and Dupuy, E.: Comparison of CMAM simulations of carbon monoxide $(\mathrm{CO})$, nitrous oxide $\left(\mathrm{N}_{2} \mathrm{O}\right)$, and methane $\left(\mathrm{CH}_{4}\right)$ with observations from Odin/SMR, ACE-FTS, and Aura/MLS, Atmos. Chem. Phys., 9, 3233-3252, doi:10.5194/acp-9-3233-2009, 2009.

Kurihara, J., Ogawa, Y., Oyama, S., Nozawa, S., Tsutsumi, M., Hall, C. M., Tomikawa, Y., and Fujii, R.: Links between a stratospheric sudden warming and thermal structures and dynamics in the high-latitude mesosphere, lower thermosphere, and ionosphere, Geophys. Res. Lett., 37, L13806, doi:10.1029/2010GL043643, 2010.

Kvissel, O.-K., Orsolini, Y. J., Stordal, F., Limpasuvan, V., Richter, J., Marsh, D. R.: Mesospheric intrusion and anomalous chemistry during and after a major stratospheric sudden warming, J. Atmos. Sol.-Terr. Phys., 78-79, 116-124, doi:10.1016/j.jastp.2011.08.015, 2012.

Labitzke, K.: The interaction between the stratosphere and mesosphere in winter, J. Atmos. Sci., 29, 1395-1399, 1972.

Limpasuvan, V., Thompson, D. W. J., and Hartmann, D. L.: The life cycle of Northern Hemisphere sudden stratospheric warmings, J. Climate, 17, 2584-2596, 2004.

Limpasuvan, V., Richter, J. H., Orsolini, Y. J., Stordal, F., and Kvissel, O.-K.: The roles of planetary and gravity waves during a major stratospheric sudden warming as characterized in WACCM, J. Atmos. Sol.-Terr. Phys., 78-79, 84-98, 2012.

Liu, H. L. and Roble, R. G.: A study of a self-generated stratospheric sudden warming and its mesospheric-lower thermospheric impacts using the coupled TIME-GCM/CCM3, J. Geophys. Res., 107, 4695, doi:10.1029/2001JD001533, 2002.

Liu, H., Jin, H., Miyoshi, Y., Fujiwara, H., and Shinagawa, H.: Upper atmosphere response to stratospheric sudden warming: Local time and height dependence simulated by GAIA model, Geophys. Res. Lett., 40, 635-640, doi:10.1002/grl.50146, 2013.

López-Puertas, M., Funke, B., Gil-López, S., von Clarmann, T., Stiller, G. P., Höpfner, M., Kellmann, S., Fischer, H., and Jackman, C. H.: Observation of $\mathrm{NO}_{X}$ enhancement and ozone depletion in the Northern and Southern Hemispheres after the October-November 2003 solar proton events, J. Geophys. Res., 110, A09S43, doi:10.1029/2005JA011050, 2005.

Manney, G. L., Krüger, K., Sabutis, J. L., Sena, S. A., and Pawson, S.: The remarkable 2003-2004 winter and other recent warm winters in the Arctic stratosphere since the late 1990s, J. Geophys. Res., 110, D04107, doi:10.1029/2004JD005367, 2005.

Manney, G. L., Daffer, W. H., Strawbridge, K. B., Walker, K. A., Boone, C. D., Bernath, P. F., Kerzenmacher, T., Schwartz, M. J., Strong, K., Sica, R. J., Krüger, K., Pumphrey, H. C., Lambert, A., Santee, M. L., Livesey, N. J., Remsberg, E. E., Mlynczak, M. G., and Russell III, J. R.: The high Arctic in extreme winters: vortex, temperature, and MLS and ACE-FTS trace gas evolution, Atmos. Chem. Phys., 8, 505-522, doi:10.5194/acp-8-505-2008, 2008a.

Manney, G. L., Krüger, K., Pawson, S., Minschwaner, K., Schwartz, M. J., Daffer, W. H., Livesey, N. J., Mlynczak, M. G., Rensberg, E. E., Russell III, J. M., and Waters, J. W.: The evolution of the stratopause during the 2006 major warming: Satellite data and assimilated meteorological analyses, J. Geophys. Res., 113, D11115, doi:10.1029/2007JD009097, 2008b.

Manney, G. L., Schwartz, M. J., Krüger, K., Santee, M. L., Pawson, S., Lee, J. N., Daffer, W. H., Fuller, R. A., and Livesey, N. J.: Aura Microwave Limb Sounder observations of dynamics and transport during the record-breaking 2009 Arctic stratospheric major warming, Geophys. Res. Lett., 36, L12815, doi:10.1029/2009GL038586, 2009.

Matsuno, T.: A dynamical model of the stratospheric sudden warming, J. Atmos. Sci., 28, 1479-1494, 1971.

McLandress, C., Ward, W. E., Fomichev, V. I., Semeniuk, K., Beagley, S. R., McFarlane, N. A., and Shepherd, T. G.: Large-scale 
dynamics of the mesosphere and lower thermosphere: An analysis using the extended Canadian Middle Atmosphere Model, J. Geophys.Res., 111, D17111, doi:10.1029/2005JD006776, 2006.

McLandress, C., Scinocca, J. F., Shepherd, T. G., Reader, M. C., and Maney, G.: Dynamical control of the mesosphere by orographic and non-orographic gravity wave drag during the extended northern winters of 2006 and 2009, J. Atmos. Sci., 70, 2152-2169, doi:10.1175/JAS-D-12-0297.1, 2013.

Merryfield, W. J., Lee, W.-S., Boer, G. J., Kharin, V. V., Scinocca, J. F., Flato, G. M., Ajaymohan, R. S., and Fyfe, J. C.: The Canadian Seasonal to Interannual Prediction System. Part I: Models and Initialization, Mon. Weather Rev., 141, 2910-2945, doi:10.1175/MWR-D-12-00216.1, 2013.

Miller, A., Schmidt, H., and Bunzel, F.: Vertical coupling of the middle atmosphere during stratospheric warming events, J. Atmos. Sol.-Terr. Phys., 97, 11-21, doi:10.1016/j.jastp.2013.02.008, 2013.

Minschwaner, K., Manney, G. L., Livesey, N. J., Pumphrey, H. C., Pickett, H. M., Froidevaux, L., Lambert, A., Schwartz, M. J., Bernath, P. F., Walker, K. A., and Boone, C. D.: The photochemistry of carbon monoxide in the stratosphere and mesosphere evaluated from observations by the Microwave Limb Sounder on the Aura satellite, J. Geophys. Res., 115, D13303, doi:10.1029/2009JD012654, 2010.

Natarajan, M., Remsberg, E. E., Deaver, L. E., and Russell III, J. M.: Anomalously high levels of $\mathrm{NO}_{\mathrm{x}}$ in the polar upper stratosphere during April, 2004: Photochemical consistency of HALOE observations, Geophys. Res. Lett., 31, L15113, doi:10.1029/2004GL020566, 2004.

Nezlin, Y., Polavarapu, S., and Rochon, Y. J.: A new method of assessing filtering schemes in data assimilation systems, Q. J. Roy. Meteorol. Soc., 135, 1059-1070, doi:10.1002/qj.418, 2009.

Orsolini, Y. J., Urban, J., Murtagh, D., Lossow, S., and Limpasuvan, V.: Descent from the polar mesosphere and anomalously high stratopause observed in 8 years of water vapour and temperature satellite observations by the ODIN submilimeter radiometer, J. Geophys. Res., 115, D12305, doi:10.1029/2009JD013501, 2010.

Polavarapu, S., Ren, S., Clayton, A. M., Sankey, D., and Rochon, Y. J.: On the relationship between incremental analysis updating and incremental digital filtering, Mon. Weather Rev., 132, 2495-2502, doi:10.1175/15200493(2004)132<2495:OTRBIA>2.0.CO;2, 2004.

Randall, C. E., Rusch, D. W., Bevilacqua, R. M., Hoppel, K. W., and Lumpe, J. D.: Polar Ozone and Aerosol Measurement (POAM) II stratospheric $\mathrm{NO}_{2}, 1993-1996$, J. Geophys. Res., 103, 2836128371, doi:10.1029/98JD02092, 1998.

Randall, C. E., Siskind, D. E., and Bevilacqua, R. M.: Stratospheric $\mathrm{NO}_{\mathrm{X}}$ enhancements in the Southern Hemisphere vortex in winter/spring of 2000, Geophys. Res. Lett., 28, 2385-2388, doi:10.1029/2000GL012746, 2001.

Randall, C. E., Harvey, V. L., Manney, G. L., Orsolini, Y., Codrescu, M., Sioris, C., Brohede, S., Haley, C. S., Gordley, L. L., Zawodny, J. M., and Russell III, J. M.: Stratospheric effects of energetic particle precipitation in 2003-2004, Geophys. Res. Lett., 32, L05802, doi:10.1029/2004GL022003, 2005.

Randall, C. E., Harvey, V. L., Sigleton, C. S., Bernath, P. F., Boone, C. G., and Kozyra, J. U.: Enhanced $\mathrm{NO}_{\mathrm{X}}$ in 2006 linked to strong upper stratospheric Arctic vortex, Geophys. Res. Lett., 33, L18811, doi:10.1029/2006GL027160, 2006.
Randall, C. E., Harvey, V. L., Singleton, C. S., Bailey, S. M., Bernath, P. F., Codrescu, M., Nakajima, H., and Russell III, J. M.: Energetic particle precipitation effects on the Southern Hemisphere stratosphere in 1992-2005, J. Geophys. Res., 112, D08308, doi:10.1029/2006JD007696, 2007.

Randall, C. E., Harvey, V. L., Siskind, D. E., France, J., Bernath, P. F., Boone, C. D., and Walker, K. A.: $\mathrm{NO}_{\mathrm{x}}$ descent in the Arctic middle atmosphere in early 2009, Geophys. Res. Lett., 36, L18811, doi:10.1029/2009GL039706, 2009.

Rees, M. H.: Physics and chemistry of the upper atmosphere, Cambridge University Press, 1989.

Ren, S., Polavarapu, S., and Shepherd, T. G.: Vertical propagation of information in a middle atmosphere data assimilation system by gravity wave drag feedbacks, Geophys. Res. Lett., 35, L06804, doi:10.1029/2007GL032699, 2008.

Ren, S., Polavarapu, S., Beagley, S. R., Nezlin, Y., and Rochon, Y. J.: The impact of gravity wave drag $\mathrm{n}$ mesospheric analyses of the 2006 stratospheric major warming, J. Geophys. Res., 116, D19116, doi:10.1029/2011JD015943, 2011.

Renard, J.-B., Blelly, P.-L., Bourgeois, Q., Chartier, M., Goutail, F., and Orsolini, Y. J.: Origin of the January-April 2004 increase in stratospheric $\mathrm{NO}_{2}$ observed in northern polar latitudes, Geophys. Res. Lett., 33, L11801, doi:10.1029/2005GL025450, 2006.

Rinsland, C. P., Boone, C., Nassar, R., Walker, K., Bernath, P., McConnell, J. C., and Chiou, L.: Atmospheric Chemistry Experiment (ACE) Arctic stratospheric measurements of $\mathrm{NO}_{\mathrm{X}}$ during February and March 2004: Impact of intense solar flares, Geophys. Res. Lett., 32, L16S05, doi:10.1029/2005GL022425, 2005.

Russell, J. M., Gordley, L. L., Park, J. H., Drayson, S. R., Hesketh, W. D., Cicerone, R. J., Tuck, A. F., Frederick, J. E., Harries, J. E., and Crutzen, P. J.: The Halogen Occultation Experiment, J. Geophys. Res., 98, 10777-10797, 1993.

Salmi, S.-M., Verronen, P. T., Thölix, L., Kyrölä, E., Backman, L., Karpechko, A. Yu., and Seppälä, A.: Mesosphere-to-stratosphere descent of odd nitrogen in February-March 2009 after sudden stratospheric warming, Atmos. Chem. Phys., 11, 4645-4655, doi:10.5194/acp-11-4645-2011, 2011.

Samson, J. A. R. and Angel, G. C.: Single- and doublephotoionization cross sections of atomic nitrogen from threshold to 31 Å, Phys. Rev., 42, 1307-1312, 1990.

Sankey, D., Ren, S., Polavarapu, S., Rochon, Y. J., Nezlin, Y., and Beagley, S.: Impact of data assimilation filtering methods on the mesosphere, J. Geophys. Res., 112, D24104, doi:10.1029/2007JD008885, 2007.

Schoeberl, M. R.: Stratospheric Warmings: Observations and Theory, Rev. Geophys. Space Phys., 16, 521-538, 1978.

Semeniuk, K., Fomichev, V. I., McConnell, J. C., Fu, C., Melo, S. M. L., and Usoskin, I. G.: Middle atmosphere response to the solar cycle in irradiance and ionizing particle precipitation, Atmos. Chem. Phys., 11, 5045-5077, doi:10.5194/acp-11-50452011, 2011.

Seppälä, A., Verronen, P. T., Cliverd, M. A., Randall, C. E., Tamminnen, J., Sofieva, V., Backman, L., and Kyrölä, E.: Arctic and Antarctic polar winter $\mathrm{NO}_{\mathrm{X}}$ and energetic particle precipitation in 2002-2006, Geophys. Res. Lett., 34, L12810, doi:10.1029/2007GL029733, 2007.

Shepherd, G. G., Thuillier, G., Gault, W. A., Solheim, B. H., Hersom, C., Alunni, J. M., Brun, J.-F., Brune, S., Charlots, P., Cogger, L. L., Desaulniers, D.-L., Evans, W. F. J., Gattinger, R. L., 
Girod, F., Harvie, D., Hum, R. H., Kendall, D. J. W., Llewellyn, E. J., Lowe, R. P., Ohrt, J., Pasternak, F., Peillet, O., Powell, T. M. I., Rochon, Y., Ward, W. E., Wiens, R. H., and Wimperis, J.: WINDII, the Wind Imaging Interferometer on the Upper Atmosphere Research Satellite, J. Geophys. Res., 98, 10725-10750, 1993.

Shepherd, G. G., Stegman, J., Espy, P., McLandress, C., Thuillier, G., and Wiens, R. H.: Springtime transition in the lower thermosphere atomic oxygen, J. Geophys. Res., 104, 213-223, 1999.

Shepherd, M. G. and Shepherd, G. G.: Stratospheric warming effects on thermospheric $\mathrm{O}\left({ }^{1} \mathrm{~S}\right)$ dayglow dynamics, J. Geophys. Res., 116, A11327, doi:10.1029/2011JA016762, 2011.

Shepherd, M. G., Cho, Y. M., Shepherd, G. G., Ward, W., and Drummond, J. R.: Mesospheric temperature and atomic oxygen response during the January 2009 major stratospheric warming, J. Geophys. Res., 115, A07318, doi:10.1029/2009JA015172, 2010.

Siskind, D. E. and Russell III, J. M.: Coupling between middle and upper atmospheric NO: Constraints from HALOE observations, Geophys. Res. Lett., 23, 137-140, doi:10.1029/95GL03782, 1996.

Siskind, D. E., Bacmeister, J. T., Summers, M. E., and Russell III, J. M.: Two-dimensional model calculations of nitric oxide transport in the middle atmosphere and comparison with halogen occultation experiment data, J. Geophys. Res., 102, 3527-3545, 1997.

Siskind D. E., Barth, C. A., and Russell III, J. M.: A climatology of nitric oxide in the mesosphere and thermosphere, Adv. Space Res., 21, 1353-1362, doi:10.1016/S0273-1177(97)007436, 1998.

Siskind, D. E., Nedoluha, G. E., Randall, C. E., Fromm, M., and Russell III, J. M.: An assessment of Southern Hemisphere stratospheric $\mathrm{NO}_{\mathbf{X}}$ enhancements due to transport from the upper atmosphere, Geophys. Res. Lett., 27, 329-332, 2000.

Siskind, D. E., Coy, L., and Espy, P.: Observations of stratospheric warmings and mesospheric coolings by the TIMED SABER instrument, Geophys. Res. Lett., 32, L09804, doi:10.1029/2005GL022399, 2005.

Siskind, D. E., Eckermann, S. D., McCormack, J. P., Coy, L., Hoppel, K. W., and Baker, N. L.: Case studies of the mesospheric response to recent minor, major, and extended stratospheric warmings, J. Geophys. Res., 115, D00N03, doi:10.1029/2010JD014114, 2010.
Solomon, S. and Garcia, R. R.: On the distribution of nitric dioxide in the high latitude stratosphere, J. Geophys. Res., 88, 52295239, 1983.

Solomon, S. C. and Qian, L.: Solar Extreme Ultraviolet Irradiance for General Circulation Models, J. Geophys. Res., 110, A10306, doi:10.1029/2005JA011160, 2005.

Solomon, S., Crutzen, P. J., and Roble, R. G.: Photochemical coupling between the thermosphere and the lower atmosphere: 1 . Odd nitrogen from 50 to $120 \mathrm{~km}$, J. Geophys. Res., 87, 7206$7220,1982$.

Solomon, S., Garcia, R. R., Olivero, J. J., Bevilacqua, R. M., Schwartz, P. R., Clancy, R. T., and Muhleman, D. O.: Photochemistry and transport of carbon monoxide in the middle atmosphere, J. Atmos. Sci., 42, 1072-1083, 1985.

Turunen, E., Verronen, P., Seppälä, A., Rodger, C. J., Clilverd, M. A., Tamminen, J., Enell, C.-F., and Ulich, C.-F.: Impact of different energies of precipitating particles on $\mathrm{NO}_{\mathrm{X}}$ generation in the middle and upper atmosphere during geomagnetic storms, J. Atmos. Sol.-Terr. Phys., 71, 1176-1189, doi:10.1016/j.jastp.2008.07.005, 2009.

Vitt, F. M., Armstrong, T. P., Cravens, T. E., Dreschhoff, G. A. M., Jackman, C. H., and Laird, C. M.: Computed contributions to odd nitrogen concentrations in the Earth's polar middle atmosphere by energetic charged particles, J. Atmos. Sol.-Terr. Phys., 62, 669-683, 2000.

Walterscheid, R. L., Sivjee, G. G., and Roble, R. G.: Mesospheric and lower thermospheric manifestations of a stratospheric warming event over Eureka, Canada $\left(80^{\circ} \mathrm{N}\right)$, Geophys. Res. Lett., 27, 2897-2900, 2000.

Ward, W. E.: A simple model of diurnal variations in the mesospheric oxygen nightglow, Geophys. Res. Lett., 26, 3565-3568, 1999.

Whiteway, J. A. and Carswell, A. I.: Rayleigh lidar observations of thermal structure and gravity wave activity in the high arctic during stratospheric warming, J. Atmos. Sci., 51, 3122-3136, 1994.

Woodall, J., Agundez, M., Markwick-Kemper, A. J., and Millar, T. J.: The UMIST database for astrochemistry 2006, Astron. Astrophys., 466, 1197-1204, doi:10.1051/0004-6361:20064981, 2007. 